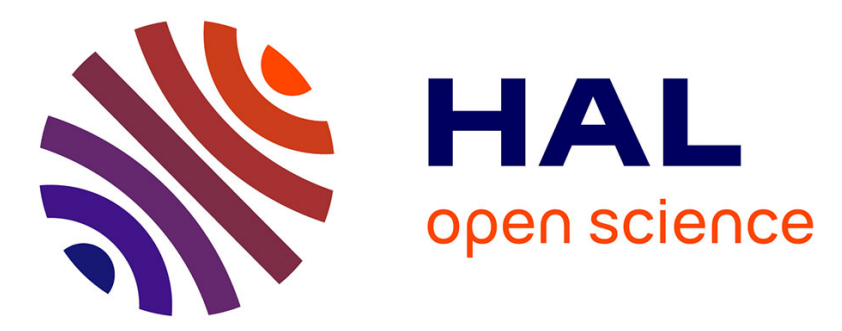

\title{
Bacterial Pigments: Sustainable Compounds With Market Potential for Pharma and Food Industry
}

Chidambaram Kulandaisamy Venil, Laurent Dufossé, Ponnuswamy Renuka Devi

\section{- To cite this version:}

Chidambaram Kulandaisamy Venil, Laurent Dufossé, Ponnuswamy Renuka Devi. Bacterial Pigments: Sustainable Compounds With Market Potential for Pharma and Food Industry. Frontiers in Sustainable Food Systems, 2020, 4, 10.3389/fsufs.2020.00100 . hal-03070846

\section{HAL Id: hal-03070846 \\ https: / hal.univ-reunion.fr/hal-03070846}

Submitted on 16 Dec 2020

HAL is a multi-disciplinary open access archive for the deposit and dissemination of scientific research documents, whether they are published or not. The documents may come from teaching and research institutions in France or abroad, or from public or private research centers.
L'archive ouverte pluridisciplinaire HAL, est destinée au dépôt et à la diffusion de documents scientifiques de niveau recherche, publiés ou non, émanant des établissements d'enseignement et de recherche français ou étrangers, des laboratoires publics ou privés.

\section{(c)(1)}

Distributed under a Creative Commons Attribution| 4.0 International License 
OPEN ACCESS

Edited by:

Miriam Dupas Hubinger, Campinas State University, Brazi

Reviewed by:

Zhilong Wang,

Shanghai Jiao Tong University, China Iramaia Angelica Neri-Numa,

Campinas State University, Brazil

${ }^{*}$ Correspondence:

Chidambaram Kulandaisamy Venil ckvenil1@gmail.com

Laurent Dufossé

laurent.dufosse@univ-reunion.fr

Specialty section: This article was submitted to

Sustainable Food Processing, a section of the journal

Frontiers in Sustainable Food Systems

Received: 22 April 2020 Accepted: 10 June 2020

Published: 21 July 2020

Citation:

Venil CK, Dufossé L and Renuka Devi P (2020) Bacterial Pigments: Sustainable Compounds With Market

Potential for Pharma and Food Industry.

Front. Sustain. Food Syst. 4:100. doi: 10.3389/fsufs.2020.00100

\section{Bacterial Pigments: Sustainable Compounds With Market Potential for Pharma and Food Industry}

\author{
Chidambaram Kulandaisamy Venil ${ }^{1 *}$, Laurent Dufossé ${ }^{2 *}$ and Ponnuswamy Renuka Devi ${ }^{1}$ \\ ${ }^{1}$ Department of Biotechnology, Anna University, Coimbatore, India, ${ }^{2}$ Université de la Réunion, CHEMBIOPRO Chimie et \\ Biotechnologie des Produits Naturels, ESIROI Département Agroalimentaire, Sainte-Clotilde, Ile de La Réunion, Indian \\ Ocean, France
}

The continued universal application of synthetic colorants for decades have caused environmental pollutions and human health vulnerabilities. So, it was indispensable to discover novel natural colorants such as microbial colorants which were safer and better than synthetic colorants. The potential of bacterial pigments for mass production of diversified coloring properties was first prospective and is now getting the notable importance and attention of both the researchers and industries. Literature establishes that the natural colorants produced from microbes were applied in food and pharma products successfully. Apart from serving as food colorants, bacterial pigments have several pharmacological activities like anti-microbial, anti-cancer, anti-oxidant, anti-inflammatory and anti-allergic properties with large economic potential. And, there is vast scope for easy and cheap production of natural colorants in all seasons from bacterial sources, compared to plant sources. Tactics in strain improvement, fermentation conditions, metabolic engineering, and easy extraction techniques are needed to produce high end products. This review highlights the significance of bacterial colorants and summarizes its application in food and pharma industries. Further, the major challenge of lower stability of bacterial pigments and the solution to address it is also appraised.

Keywords: natural colorants, bacterial colorants, scale-up, genetic engineering, food grade pigments, pharmacological activities, challenges, instability

\section{INTRODUCTION}

Industries of late, have resorted to use many important microbial metabolites like antibacterials, antifungals, vitamins, enzymes, pigments, etc., for varied applications as being alternative ones to synthetic products. Changing nature of such kind of the industrial behavior have enthused both academia and industries to discover renewable and biodegradable natural products from microbial resources. Nevertheless, the task of discovering potent novel microbial pigments for the optimal applications in food and pharma products, in spite of several research studies is still a challenging one requiring appropriate approaches (Sen et al., 2019) and this review suggests the ways and means to overcome such challenges in this field. 
The production of microbial pigments has two basic approaches:

a) Finding new strains of pigment producing microbes from diverse environments and enhance their productivity.

b) Achieving enhanced yields from the already recognized species either by strain improvement and process development.

Currently, the use of natural colorants has been encouraged and protected by laws and this inclination will continue in the coming years too. Public opinion toward natural colorants is encouraging due to their safety and biodegradable capabilities besides their production economy. Natural stains are slowly replacing synthetic colorants and this change has encouraged the possibilities for the high production of natural dyes and pigments and their sustainable utilization in all prospective fields. Yet there are many challenges in front of us; as natural colorants are sometimes less stable and covering a limited range of shades only and are not extensively exploited like current artificial colorants. Moreover, they require substantial material to attain equivalent color strength (Rodriguez-Amaya, 2016). Amidst various hurdles, the most important hurdles in the production of natural colorants are getting regulatory approval for new products and developing natural colorants which can resist to heat, light and acidic environments. Focusing the investigations more on the prospects of genetic engineering and up-scaling the pigment production.

Growth drivers for natural colorants

- There is an increased awareness on the harmful influence of synthetic colorants and the resultant boosts in the demand for natural colorants.

- In some international markets, there are restrictions and limitations in manufacturing and trading of synthetic colorants which drives toward alternate natural colorants.

- There is an increase in demand to color unique products like toys, crayons, textile printing, hand-made paper etc. using natural colorants.

The prospective of bacterial pigments in health care has stimulated attention toward the search for alternate natural colorants. These colorants receive significant consideration because of strict rules and regulations applied to synthetic pigments. The advances in fermentation processes have enabled the bacterial pigment production to reach business scale. However, two existing fundamental issues are to be addressed: (1) economic and (2) marketing difficulties. So, alternative strategies such as smarter screening methods, apt fermentation processes, cost-effective down streaming, genetic engineering for strain improvement etc. should be involved more effectively in valued natural pigment production from bacteria (Ramesh et al., 2019). Such approaches would be a matter of great interest on the production of natural pigments and its economics from industrial perspectives (Majumdar et al., 2019). This review appraises the issues of bacterial colorants, fermentation strategies, genetic engineering for strain improvement, scale up of bacterial colorants from lab scale to industrial level, pharmacological applications, food colorants besides the stability issues of bacterial colorants.

\section{INDUSTRIAL IMPORTANCE AND MARKET POTENTIAL}

Owing to the hazardous nature of synthetic colorants, the current exploitations and the prospective of microbial pigments as natural colorants in the food industry are promising. Food and Drug Administration (FDA) already approved pigments existing in the market such as riboflavin (Ashbya gossypii), $\beta$-carotene and lycopene (Blakeslea trispora), Arpink Red (Penicillium oxalicum), astaxanthin (Xanthophyllomyces dendrorhous), and Monascus pigments (Venil et al., 2013). FDA and EFSA (European Food Safety Authority) assess the safety of food additives through international guidelines and codes of practice. During the assessment process, the need for color requirement must be described with strict toxicity testing prior to inclusion for assessment. Also, when there are changes in the manufacturing conditions for food applications, safety of additives have to be reexamined (Scotter, 2015).

The estimation of the universal food colorant market is anticipated to touch 3.75 billion USD by 2022 . The marketplace is determined by the organizations' procedures to develop item claim through colorants, interest in clean name items, and headway in scientific novelties. The farming colorant market is anticipated to grasp 2.03 billion USD by 2022 (www.bccresearch. com). The global market polls estimated the market potential of carotenoids for the years 2018-2024 in foods, beverages, pharmaceuticals, cosmetics, animal feed and dietary supplements as $26.1,9.2,6.5,34.8$, and $23.5 \%$, respectively. Presently, $80-90 \%$ of the carotenoid synthesis is fulfilled by chemical synthesis (Saini and Keum, 2019). The market value of natural carotenoids is less (24\%) than synthetic carotenoids (76\%) because of their high cost (Market Research Report, 2016). The low cost of synthetic carotenoids ( $\$ 250-2,000 \mathrm{~kg}^{-1}$ ) is the main factor behind its huge market, whereas natural carotenoids have higher market values (\$350-7,500 $\mathrm{kg}^{-1}$ ) according to the Deinove biotechnology company (Deinove, 2019). The plant-derived carotenoids are expensive and hence scientific interest in bacterial carotenoid production has escalated in recent years because of their sustainability and cost-effectiveness (Ram et al., 2020).

Carotenoids have many medicinal and health-improving properties and are also utilized in nutraceuticals, make-ups, pharmaceuticals and their usage is probably going to be expanded in the following years. Thus, carotenoids are considered as profitable business prospects for the food, healthcare and beautifying agent ventures sooner rather than later (Sathasivam and $\mathrm{Ki}, 2018$ ). The worldwide carotenoid (astaxanthin, betacarotene, canthaxanthin, lutein, lycopene, zeaxanthin) platform is evaluated to be at USD 1.53 billion by 2021 . The important carotenoid-containing biomass from Haematococcus sp. and Chlorella sp. are sold at a cost of 40-50 USD per kg in the open market. $ß$-carotene acts as an antioxidant and destroys the impact of free radicals in the human assimilation up-to numerous folds 
(Fiedor and Burda, 2014). Mounting interest for beta-carotene because of its high viability and therapeutic properties is setting off the market for beta-carotene. Astaxanthin market is foreseen to reach USD 814.1 million by 2022 at a CAGR of $8.02 \%$ from 2017. Europe has moved emphatically toward the utilization of natural colorants and leads the way and they utilize $85 \%$ of natural colorants (www.bccresearch.com). Expanding interest for processed and ready to eat food in India, China and Middle-East is expected to drive food colorant market in Asia Pacific.

\section{DIFFERENT SHADES OF BACTERIAL PIGMENTS}

Eco-friendly and non-toxic bacterial colorants are gradually replacing synthetic colorants in food, pharmaceuticals, textiles and cosmetics (Chiba et al., 2006). The current concern is on producing coloring materials using microbes (Usman et al., 2017). Pigment synthesis depends upon the microbes and fermentation conditions. Pigment production in a mini bioreactor should be carried out before proceeding to a pilot plant for commercial production (Banerjee et al., 2013).

Microbial pigments include astaxanthin, canthaxanthin, carotenoids, melanins, granadaene, indigoidine, flavins, quinones and more specifically monascins, prodigiosin, pyocyanin, rubrolene, scytonemin, violacein, phycocyanin possessing various activities like anti-oxidant, anti-carcinogenic, anti-inflammatory and anti-obesity properties (Table 1) (Fernandez-Orozco et al., 2011; Kim et al., 2011). Bacterial pigments can magnify the existing palette of colors used in numerous applications. Bacterial pigments are considered safe and can be used as natural colorants which will benefit the human health and save the ecosystem (Malik et al., 2012). Many promising carotenoid producing bacterial strains belonging to Arthrobacter, Flavobacterium, Chryseobacterium and Zobellia genera were isolated from King George Island, Antarctica. They produce 10 different carotenoids like zeaxanthin, $\beta$-cryptoxanthin and $\beta$-carotene (Vila et al., 2019).

Bacteria produce different shades of color like red (Serratia marcescens, Gordonia jacobaea), red-yellow (Kocuria sp., Chryseoacterium artocarpi), yellow (Micrococcus, Hymenobacter sp. and Chryseobacterium sp.), green (Pseudomonas sp.), blue (Corynebacterium insidiosum, Erwinia chrysanthemi, Vogesella indigofera), purple (Chromobacterium sp.) as shown in Munsell color system (Figure 1).

\section{GENETIC ENGINEERING FOR STRAIN IMPROVEMENT}

Through genetic engineering, bacteria could be modified to produce pigment of interest. The remarkable increase in fermentation efficiency and the subsequent decrease in cost have made it possible through mutagenesis to select prospective pigment producing strains (Venil et al., 2014; Rao et al., 2017). Protein engineering by random and rational approaches is possible through the developments in metabolic engineering. These approaches may support the improvement of pigment production biologically. The use of recombinant microorganisms provides pathway to modify the active components to develop standard pigments with attractive pharmaceutical properties. To produce valuable bacterial pigments in good qualities, genetic engineering has proven to be highly active in a value effective manner (Numan et al., 2018). Pigment producing bacterial strain was engineered to overproduce pigment and thereby changing the color and structure. The blue pigment, actinorhodin producing Streptomyces coelicolor has been genetically engineered to produce bright yellow polyketide, kalafungin and used to produce anthraquinone type pigment. The cell factories to effectively produce pigments has been developed by heterologous expression by biosynthetic pathway from known pigment producers (Sankari et al., 2018). The biosynthetic pathway for microbial pigments is fully understood by identifying and engineering the genes for overproduction. Cloning the pigment biosynthesis gene into microbial vectors like $E$. coli, Bacillus subtilis, Pseudomonas putida, Corynebacterium glutamicum, Pichia pastoris is the cost-effective and economic way for industrial production processes (Sen et al., 2019). The carotenogenic genes from Xanthophyllomyces dendrohous or Agrobacterium aurantiacum are genetically modified to produce carotenoids (lycopene, astaxanthin, $\beta$-carotene) (Heider et al., 2014).

The biosynthetic pathways of bacterial pigments have delivered chances for heterologous gene expression in recombinant bacteria. The advancement in genetic engineering would make bacterial pigments available in market, if the genomes of native pigment producing bacteria could be altered suitably. The genetic engineering is encouraged by the possible industrial uses wherever value-added strategies for developing strains are adopted to enhance the pigment production (Saini et al., 2020). The genetic engineering of bacteria to produce higher level of pigments is highly possible through biotechnology (Pham et al., 2019).

The targets for pigment production through genetic engineering include red (lycopene), orange ( $\beta$-carotene) and the purple (violacein) pigment producing bacteria that contributes significantly for pigment production. Alper et al. (2005), Farmer and Liao (2001), and Yoon et al. (2006) studied the overproduction of lycopene and isoprenoids through genetic engineering and testified that they possess industrial significance (Ajikumar et al., 2010). Because of the various prospective applications of violacein as antimicrobial and antitumor agents, it has been the major topic of research in metabolic engineering.

Pseudomonas sp. produces blue pigment, pyocyanin comprised of N-methyl-1-hydroxyphenazine; MvfR gene, producing a transcription factor activates phnAB genes (Norman et al., 2004). Mavrodi et al. (2001) studied that these genes produce quinolone, which are important for pyocyanin synthesis. Jayaseelan et al. (2014) have analyzed the antimicrobial activity of pyocyanin and its use as bio-control agents. Melanin has various applications and widely used in cosmetics, eyeglasses, sunscreens etc. Melanin is produced by Bacillus sp., Pseudomonas sp., and is used to screen recombinant strains and in the treatment of metastatic melanoma (Surwase et al., 2013). 
TABLE 1 | Bacterial pigments with high potential to be used as natural colorants.

\begin{tabular}{|c|c|c|c|c|c|}
\hline Bacteria & Pigment & Color & Bioactivity & Status & References \\
\hline $\begin{array}{l}\text { Agrobacterium aurantiacum } \\
\text { Paracoccus } \\
\text { carotinifaciens }\end{array}$ & Astaxanthin & Pink-Red & $\begin{array}{l}\text { Antioxidant, anticancer } \\
\text { Anti-inflammatory, antioxidant } \\
\text { Anticancer }\end{array}$ & $\mathrm{RP} / \mathrm{IP}$ & Ambati et al., 2014 \\
\hline Bacillus cereus & Azaphenanthrene & Green & Anticancer, antibacterial, textile dyeing & $\mathrm{RP}$ & Banerjee et al., 2011 \\
\hline $\begin{array}{l}\text { Rhodococcus maris } \\
\text { Kocuria sp. }\end{array}$ & $\begin{array}{l}\text { Beta-carotene } \\
\text { Carotenoids }\end{array}$ & $\begin{array}{l}\text { Bluish-Red } \\
\text { Yellow }\end{array}$ & $\begin{array}{l}\text { Used to treat various disorders such } \\
\text { as erythropoietic protoporphyria. } \\
\text { Reduces the risk of breast cancer } \\
\text { Anti-cancer activity }\end{array}$ & DS & Kirti et al., 2014 \\
\hline $\begin{array}{l}\text { Bradyrhizobium sp. } \\
\text { Lactobacillus pluvialis }\end{array}$ & Canthaxanthin & Orange & Antioxidant, anticancer & $\mathrm{RP}$ & Dufossé, 2006; Ram et al., 2020 \\
\hline Chryseobacterium artocarpi & Flexirubin & $\begin{array}{l}\text { Yellowish- } \\
\text { Orange }\end{array}$ & $\begin{array}{l}\text { Treatment for chronic skin disease, } \\
\text { eczema, gastric ulcers }\end{array}$ & $\mathrm{RP}$ & Venil et al., 2015 \\
\hline Streptococcus agalactiae & Granadaene & Orange-Red & Antioxidant, detoxify ROS & DS & George and Nizet, 2009 \\
\hline Proteobacteria & Heptyl prodigiosin & Red & Antiplasmodial & DS & Lazaro et al., 2002 \\
\hline $\begin{array}{l}\text { Corynebacterium insidiosum } \\
\text { Erwinia chrysanthemi }\end{array}$ & Indigoidine & Blue & $\begin{array}{l}\text { Protection from oxidative stress } \\
\text { Antioxidant } \\
\text { Antimicrobial }\end{array}$ & NK & Reverchon et al., 2002; Chu et al., 2010 \\
\hline Pseudomonas guinea & Melanin & Black & Antioxidant activity & NK & Tarangini and Mishra, 2013 \\
\hline Pseudomonas sp. & Phenazine & Yellow & Biological control & NK & Arseneault et al., 2013 \\
\hline Pseudomonas sp. & Phycocyanin & Blue, Green & $\begin{array}{l}\text { Cytotoxicity, neutrophil apoptosis, } \\
\text { proinflammatory }\end{array}$ & $\mathbb{I P}$ & Murugan, 2012 \\
\hline $\begin{array}{l}\text { Serratia marcescens } \\
\text { Pseudoalteromonas rubra }\end{array}$ & Prodigiosin & Red & $\begin{array}{l}\text { Anticancer, DNA cleavage, } \\
\text { immunosuppressant }\end{array}$ & IP & $\begin{array}{l}\text { Melvin et al., 2000; Deorukhkar et al., } \\
\text { 2007; Feher et al., } 2008\end{array}$ \\
\hline Bacillus sp. & Riboflavin & Yellow & Nutritional supplement & $\mathrm{RP}$ & Lim et al., 2001 \\
\hline Bacillus subtilis & Riboflavin & Yellow & Food additives & & Schwechheimer et al., 2016 \\
\hline Streptomyces echinoruber & Rubrolone & Red & Antimicrobial & DS & Dharmaraj et al., 2009 \\
\hline Staphylococcus aureus & Staphyloxanthin & Golden & Antioxidant, detoxify ROS & NK & Liu et al., 2005a,b; Clauditz et al., 2006 \\
\hline Cytophaga/Flexibacteria & Tryptanthrin & $\begin{array}{l}\text { Light dark } \\
\text { yellow }\end{array}$ & Antioxidant, anticancer & NK & Solieve et al., 2011 \\
\hline Streptomyces sp. & $\begin{array}{l}\text { Undecyl } \\
\text { prodigiosin }\end{array}$ & Red & $\begin{array}{l}\text { Antibacterial, antioxidative, } \\
\text { UV-protective, anticancer }\end{array}$ & NK & $\begin{array}{l}\text { Liu et al., 2005a,b; Stankovic et al., } \\
2012\end{array}$ \\
\hline $\begin{array}{l}\text { Janthinobacterium lividium, } \\
\text { Pseudoalteromonas tunicate, } \\
\text { Chromobacterium violaceum }\end{array}$ & Violacein & Purple & $\begin{array}{l}\text { Anti-bacterial, anti-viral, } \\
\text { anti-leukemic, anti-fungal, } \\
\text { anti-parasitic, anti-protozoal, } \\
\text { anti-oxidant and anti-ulcerogenic. }\end{array}$ & NK & Venegas et al., 2019 \\
\hline Xanthomonas oryzae & Xanthomonadin & Yellow & $\begin{array}{l}\text { chemotaxonomic and diagnostic } \\
\text { markers }\end{array}$ & NK & Schoner et al., 2014 \\
\hline $\begin{array}{l}\text { Flavobacterium sp., } \\
\text { Paracoccus sp. }\end{array}$ & Zeaxanthin & Yellow & Photo protectant, antioxidant & DS & Berry et al., 2003 \\
\hline
\end{tabular}

Industrial status adopted from Dufossé (2018).

DS, Development stage; IP, Industrial production; RP, Research project; NK, Not Known.

Sphingobacterium multivorum produces zeaxanthin and utilize deoxyxylulose-5-phosphate (DXP) pathway for its enhanced production (Ram et al., 2020). Numerous bacteria were explored for IPP biosynthesis, mevalonate and DXP pathways. Additionally, the identification of genes (IPP biosynthesis) in metabolic engineering of bacteria have increased the production of carotenoids (Lange et al., 2000; Calegari-Santos et al., 2016; Dufossé, 2018). Isorenieratene and the derivatives, the aryl carotenoids, are not attainable for industrial applications (Valla et al., 2003). Aryl carotenoids produced in culture medium by Brevibacterium linens is insufficient for commercialization and researchers have developed novel syntheses. Nevertheless, genetic modifications of pigment producing bacteria with potent antioxidant activity could be a substitute for carotenoids (polyenic-phenolic) (patent application WO 2008009675).

Violacein has been produced by Chromobacterium violaceum (Durán and Menck, 2001), Janthinobacterium lividum (Pantanella et al., 2007), Pseudoalteromonas luteoviolacea (Thogersen et al., 2016), Duganella sp. (Wang et al., 2009), Collimonas sp. (Choi et al., 2015a), and Pseudoalteromonas sp. 520P1 and 710P1 (Yada et al., 2008). Many researchers have cloned and expressed the genes for violacein production which occur within a single operon, vioABCDE (Kothari et al., 2017) and they have cloned and expressed these genes in other bacterial hosts, including E. coli (Rodrigues et al., 2013). A cosmid vector, pHC79, was cloned by violacein gene cluster 


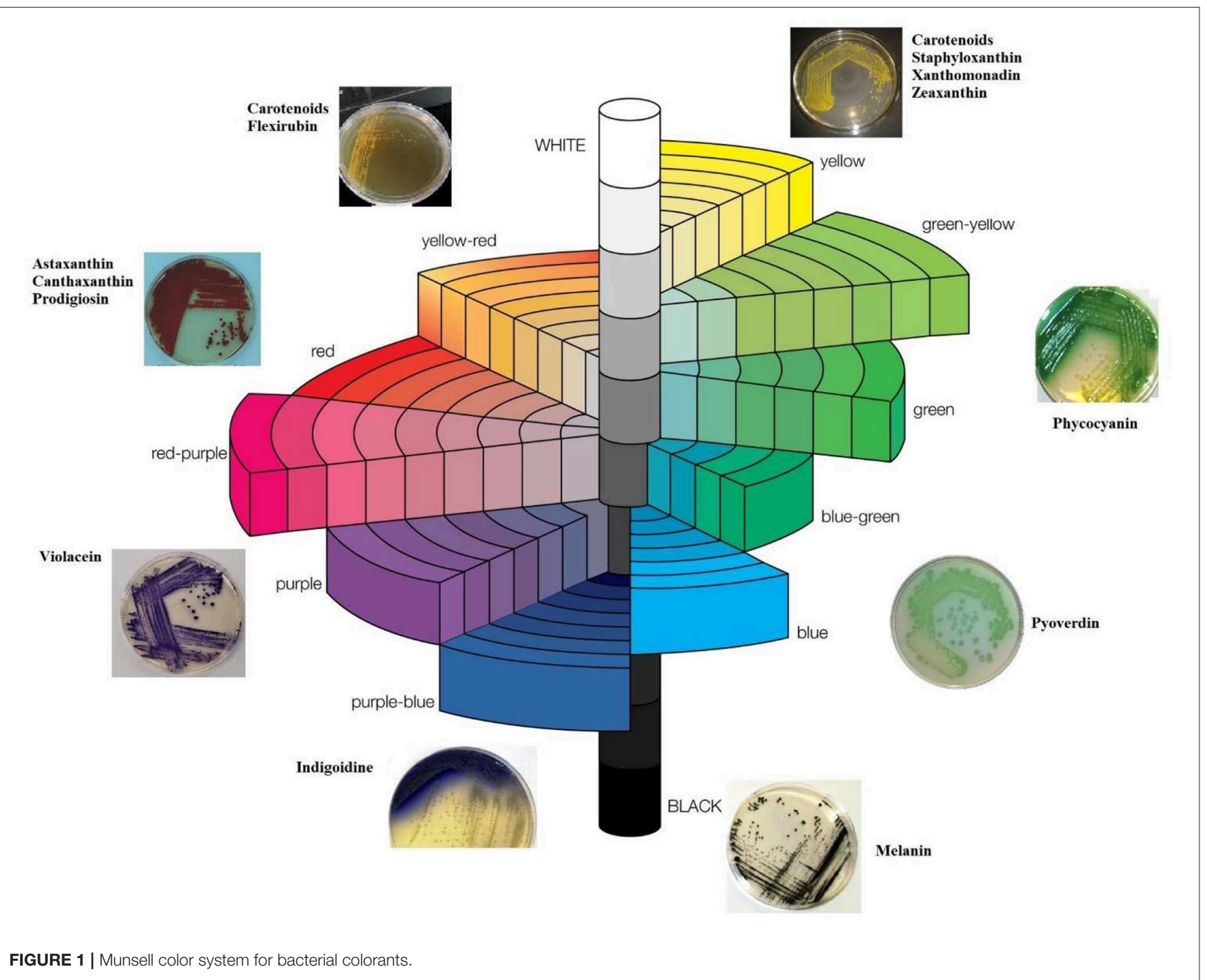

and this was unstable and lost more than $50 \%$ of the bacterial growth at 15th generations (Choi et al., 2015b). The vioABCDE operon in pUC18 vector generates stable IncP plasmid and this plasmid is more stable for 100 generations without antibiotics, making it a valuable tool for violacein production (Ahmetagic and Pemberton, 2010).

For bacterial pigments, the biosynthetic pathway is a very crucial step and this is followed by identification and engineering the genes responsible for production of pigments (Sen et al., 2019). Cloning the pigment genes to microbial vectors (E.coli, Bacillus subtilis, Corynebacterium glutamicum, Pichia pastoris) is a cost-effective process for industrial fermentation. CRISPR (Clustered Regularly Interspaced Short Palindromic Repeats)CAS9 technology in genetic engineering has lately been used for the large scale production of bioactive components. The colorant gene is injected into its genome via CRISPR-CAS9 system to engineer and produce natural colorants (Sen et al., 2019).

The carotenoid production, mainly $\beta$-carotene and torularhodin from R.mucilaginosa $\mathrm{KC} 8$ is enhanced using metabolic engineering and mutagenesis (Wang et al., 2017). The ultimate aim of metabolic engineering is higher production with downstream process and purification (Watstein et al., 2015). High carotenoid contents can be achieved by over expressing the isopentenyl-diphosphate delta-isomerase and 1-deoxy-Dxylulose-5-phosphate synthase gene in the DXP pathway (Choi et al., 2010). E.coli mutant was created by inserting carotenoid biosynthetic genes from Deinococcus wulumuqiensis, resulting in a 2.2-fold increase in lycopene production compared to wild strains (Xu et al., 2018). Metabolic engineering for strain improvement leads to the development of highly efficient strains producing pigments catering for industrial needs (Aruldass et al., 2018). The production of lysine and astaxanthin from Corynebacterium glutamicum was achieved when modified through chromosomal deletion and integration using suicide vector pK19mobsacB (Henke et al., 2018). Rhodobacter sphaeroides was genetically re-designed to obtain enhanced production of lycopene (Su et al., 2018). Park et al. (2018) have reported that with latest computational prediction tools, the use 
of flux variability scanning based on the enforced objective flux algorithm to identify amplified gene targets, has resulted in to produce high content of astaxanthin in E.coli.

Advancement of the metabolic engineering in the industry sector will necessitate further large scale fermentation. Baseline methods for pigment production at laboratory level has been achieved in many studies and further researches centering on the increased production in terms of pathway design and structure are necessary. This trend will move metabolic engineering strategies beyond production of colorants to valuable natural products with prospective applications in pharmaceuticals, cosmetics, food industry etc. The expansion of engineering tools will also widen the scope for pigment production and this field is in the rise. It will be interesting to observe the future outcomes of metabolic engineering with new streams by altering the metabolome of pigmented bacteria (Yadav et al., 2012). The success of metabolic engineering is the beginning of sustainable biotechnological production. The strain development targets will be increased by genome, proteome and system biology. The breakthroughs in metabolic engineering will boost up microbial biotechnology on pigment production (Kumar and Prasad, 2011).

\section{Genome Shuffling}

Genome shuffling is the latest development for phenotypic enhancement that has established major attention toward industrially important strains (Magocha et al., 2018). The advantage of this technique is that genetic changes can be made in a microorganism without knowing its genetic background i.e., simplicity and does not require expensive genetic tools. Genome shuffling can induce mutations at diverse points for complex phenotypes without genomic data of the targeted strains (BiotPelletier and Martin, 2014). Violacein pathway is reported for the first time in Saccharomyces cerevisiae and expressed by Lee et al. (2013b). The high violacein producing strains can be screened by a combinatorial method thereby increasing the metabolic flux in this pathway. By chromosome rearrangement and modification by SCRaMbLE, the prodeoxyviolacein production is improved in haploid yeast (Wang et al., 2017). Genetic engineering will play a central role in the development of high pigment producing strains and counters high capital investment by warranting a successful commercialization.

\section{FERMENTATION STRATEGIES}

Fermentation strategies are widely used to meet the market demands for the enhanced production of bacterial pigments which have wide-ranging uses in pharmaceutical, chemical and food industries. Commercial production of bacterial pigment is possible when fermentation technology combined with genetic engineering technology is applied in achieving high yields of pigments. Bacterial pigments cannot be compared with synthetic pigments because of its low yield (Nasrabadi and Razavi, 2011). Different types of fermentation strategies are employed and they can be determined by the type of strains used and pigments extracted (Nigam and Luke, 2016).
Medium optimization is the most critical strategy for large scale production to meet the market demand. In earlier times, medium optimization was conducted using traditional methods which is time consuming, costly and have numerous trial runs. Medium optimization is becoming more effective, economical and robust with the advancement of current mathematical and statistical methods (Singh et al., 2016). Many researches claim that substantial improvements for medium optimization were achieved using experimental designs. Response surface methodology (RSM) was applied to improve fermentation parameters by avoiding unnecessary addition of components to the medium and to meet the nourishing demand for pigment producing bacteria. In addition to estimating the association of the medium components and product yield, the concentration of medium components also are evaluated to reach maximum production. By optimizing the carbon and nitrogen sources, high pigment production at higher concentration can be attained (Wang et al., 2011). However, RSM has some limitations in designing an objective function. The reliability of the technique will be confronted by the interaction between the factors and the response, which will increase the difficulty of the study (Pal et al., 2009; Kim et al., 2011). To overcome the drawbacks and to continually improve the efficiency of the RSM, various optimization algorithms have been designed over the past few decades.

In this perspective, Artificial Neural Networks (ANNs) are applied in modeling of biological systems and gained attractiveness in the intelligent decision making. Prior specification is not required in ANN and it can optimize non-linear functions. Pilkington et al. (2014) reported that ANN will have higher accurateness than RSM. The ANN comprises three layers of information known as input layer, hidden layer and output layer and is appropriate for medium optimization as it creates data containing hidden pattern.

Particle Swarm Optimization (PSO) algorithm, an easy to program one, offers more attractive choice over other methods to enhance non-linear hitches with multi-variables (Wang et al., 2008). Kennedy and Eberhart introduced Particle swarm optimization (PSO) (Du and Swamy, 2016), involving simulating behaviors to find the most suitable results. Literature exposes that several PSO optimization strategies in task scheduling (Jamali et al., 2016; Prathibha et al., 2017), medical (Jothi, 2016; Ryalat et al., 2016), oil and gas (Salehi and Goorkani, 2017; Siavashi and Doranehgard, 2017), batik production (Soesanti and Syahputra, 2016) have been positively applied in biochemical processes because of their controlled parameters to solve optimization problems (Liu et al., 2008).

Expensive synthetic medium demands an alternative cost effective fermentation process for pigment production from natural resources. Bacteria is one of the important source of pigment due to its breeding ease and abundance. Production of pigment from bacteria is subjective to various constraints like, $\mathrm{pH}$, temperature, agitation, aeration, carbon source and nitrogen source (Tuli et al., 2015). However, pigments have to be produced in large quantities in a shorter time by integrating the bacterial pigments into preferred products. So, optimizing the bacterial growth is mandatory to find suitable physical factors. 
Following further experiments, these factors on bacterial growth identify suitable conditions for the growth of bacteria to boost the pigment production. Musa and Yusof (2019) conducted a study which emphasized the key parameters to enhance the bioactivity and production of bacterial pigments for their commercial use in various industrial fields. The violet and red bacteria maximized the production in the presence of light with low shaking speed whereas the yellow bacteria enhanced the production in the absence of light with high shaking speed.

Bacterial pigments can be produced both by submerged and solid state fermentations. The production of $\beta$-carotene increased by 3.47-fold in submerged fermentation by the upregulation of carotenoid biosynthetic genes in Exiguobacterium acetylicum S01 under optimized conditions of $1.4 \mathrm{~g} / \mathrm{L}$, peptone $26.5 \mathrm{~g} / \mathrm{L}$, $\mathrm{pH} 8.5$, and temperature $30^{\circ} \mathrm{C}$ (Jinendiran et al., 2019). In solid state fermentation, bacteria are cultivated on the surface of solid substrates/agro-industrial waste which ultimately saves the medium cost and thereby acting as a waste management tool too (Tuli et al., 2015). Solid state fermentation provides adequate environment for microbes to grow and simultaneously produce higher pigment with less cost of production (Ring et al., 2018). In SSF, substrates are utilized very slowly and steadily and hence the same substrates can be used for longer fermentation process (Panesar et al., 2015). Agro-industrial waste can be utilized to lower the production cost and to protect the environment. $\beta$-carotene from Rhodotorula rubra was produced in a fruit waste medium obtained from orange, pomegranate and pineapple waste (Korumilli and Mishra, 2014). Carotenoids are produced using whey filtrate and peat extract; whereas riboflavin and astaxanthin produced in grape must, beet molasses. These are interesting prospects for pigment production using agroindustrial wastes (Korumilli and Mishra, 2014). A wide range of bacterial strains such as Serratia marcescens, Pseudomonas magneslorubra, Vibrio psychroerythrous, Serratia rubidaea, Vibrio gazogenes, Alteromonas rubra, Rugamonas rubra, Streptoverticillium rubrireticuli, and Streptomyces longisporus have shown their potential in pigment production utilizing agro-industrial waste (Venil et al., 2020).

\section{SCALE-UP FROM PETRI DISH TO LAB SCALE AND INDUSTRIAL FERMENTERS}

Pigment production depends up on the bacteria and the physico-chemical parameters during fermentation and hence it is an essential requisite to analyse the pigments in a lab scale fermenter before scaling up in industrial fermenters. The product formation during scale-up from shake flasks to benchscale bioreactors and commercial bioreactors is influenced by the physical, chemical and biological factors on bacterial growth. Mimicking the environment in different stages of scale up and the associated challenges arised needs to be addressed initially for different bacteria and their pigments (Wehrs et al., 2019). The main difference in physical stress between lab-scale and large-scale is operating pressure. As the volume in the bioreactor increases, height of the water column creates hydrostatic pressure gradient. This pressure directly influences the enzyme activity, cell membrane permeability that are vital to cell viability and metabolic flux (Lara et al., 2006). In commercial bioreactor, the hydrostatic pressure increases the concentration of dissolved gases, thereby affecting the medium $\mathrm{pH}$. The chemical stress in large scale production is the imperfect mixing which results in gradients of parameters like $\mathrm{pH}$, temperature, dissolved oxygen and also the concentration of the nutrients (Deparis et al., 2017).

The most important chemical stress in large scale production arise from raw material and microbial contaminants. To minimize the production cost, agro-industrial residues like molasses, sugarcane juice, sugar beet juice, agro residues etc. are utilized for pigment production. Microbial contamination of raw materials can further increase the deleterious impurities and reduce the production quality (Mukhopadhyay, 2015; Mohammed et al., 2017). These factors should be addressed at the early stage of strain cultivation i.e., in shake flasks where sterile and pure raw materials are commonly used for screening and optimization. The strain improvement via genetic engineering would address these issues and process scaling will be more predictable in developing novel bacteria as production forum for pigments. Regulatory approval, toxicity, stability and investment are the key bench marks for bacterial pigments to bring the colorants from Petri dish to market (Malik et al., 2012). Monascus pigment has been prohibited in Europe and United States due to the presence of mycotoxin but used in Asia for centuries as a food colorant (Dufossé et al., 2005). Therefore, researches are now focusing to develop strains that can withstand extreme $\mathrm{pH}$ and temperature to meet industrial standards and also to avoid toxin producing strains for its potential application.

\section{PHARMACOLOGICAL ACTIVITIES}

Bacterial pigments have shown their efficiency to treat various diseases and have antimicrobial, anticancer and immunesuppressive properties. Bacterial pigments have substantial clinical uses for diagnosing diseases like cancer, leukemia, diabetes mellitus etc. (Kumar et al., 2015). The bacterial pigment, melanin protect the human skin from UV radiation and is used as sun cream blocks (Rao et al., 2017).

Bioactive compounds of bacterial isolates like, prodigiosin (red), violacein (violet), flexirubin (yellowish-orange), carotenoids (yellow - orange) and pyocyanin (blue-green) serve as novel compounds for antimicrobial, antiviral, antitumor, antiprotozoa, antioxidant, anticancer and much more activities. In tune with these characteristics of the bioactive compounds of bacteria, Solieve et al. (2011) too have earlier reported that red pigment has highest antibacterial activity followed by orange, yellow and green pigments.

The xanthophylls (adonirubin and astaxanthin) act as nutraceuticals that prevents cancers, heart attacks and strokes (Long, 2004; Kim et al., 2012a). Astaxanthin (red pigment) is a valuable carotenoid that has great potential in pharmaceuticals and feed industry. Li et al. (2018) have also confirmed that prodigiosin has strong therapeutic potential and anticancer properties. Moreover, prodigiosin has valuable applications as it possesses anti-bacterial, anti-fungal, anti-protozoal, 
cytotoxic, and anti-inflammatory properties (Panesar et al., 2015). Earlier, Kim et al. (2008) have reported that the pigment from Hahella chejuensis possesses immuno suppressant and antitumor properties.

\section{Antimicrobial Activities}

The foremost human health issue is the infection caused by the multidrug resistant (MDR) bacteria that are resistant to commercial antibiotics (Van-Duin and Paterson, 2017). The Center for Disease Control and Prevention (CDC) has categorized numerous disease causing bacteria such as the extended spectrum $\beta$-lactamase (ESBL) Enterobacteriaceae, methicillin-resistant Staphylococcus aureus (MRSA), Mycobacterium tuberculosis and Streptococcus pneumoniae as serious threats (Center for Diseases Control and Prevention, 2018). The investigation of new antibiotic candidates is instantly required to overcome this issue. Venil et al. (2013) have reported that bacterial pigments like melanins, carotenoids, flavins, monascins, quinones, and violacein possesses anti-microbial properties.

The multi-drug resistant bacteria like Acinetobacter baumannii, Enterobacter aerogenes, E. coli, MRSA and Staphylococcus hemolyticus were inhibited by orange-pigmented bacteria Pseudoalteromonas flavipulchra isolated from an Indonesian stony coral (Ayuningrum et al., 2017). The marine pigmented bacteria are reported to produce potent antimicrobial compounds such as marinoazepinone $\mathrm{B}$; marinoquinoline I; marinopyrazinone $\mathrm{B}$; marino-quinolines $\mathrm{A}, \mathrm{C}$ and $\mathrm{D}$ (Choi et al., 2015; Romanenko et al., 2015; Kalinovskaya et al., 2017). Sibero et al. (2019) have isolated and identified yellow pigment ( $\beta$-carotene) producing bacterium from an unidentified coral as Vibrio owensii TNKJ.CR.24-7 (MH488980.1) and the crude pigment extract inhibited ESBL E.coli, Klebsiella pneumoniae and MRSA strains. Selvameenal et al. (2009) have reported that Streptomyces hygroscopicus producing yellow pigment showed activity against MRSA, VRSA, and ESBL cultures.

Suresh et al. (2015) have characterized the proteinaceous red pigment from Halolactibacillus alkaliphilus MSRD1 isolated from seaweed of marine environment and reported that the pigment inhibited Staphylococcus aureus and Salmonella typhi. The pigments extracted from Rhodotorula glutinis with mutagens (UV irradiation and sodium azide) have more antibacterial activity (120-fold higher) compared to the wild strains. According to Bhosale and Gadre (2001), the pigments had more antibacterial effect on Gram positive bacteria (sensitive to the pigment) than Gram negative bacteria. Srilekha et al. (2017) have isolated a novel marine strain Salinicoccus sp. producing pinkish-orange pigment and reported that the pigment exhibited maximum antimicrobial activity against Staphylococcus aureus and minimum activity against Klebsiella pneumonia and Pseudomonas aeruginosa.

Duran et al. (2012) isolated a bacterial strain RT102 containing the mixture of violacein and deoxyviolacein and reported its antibacterial activity against Gram positive and Gram negative bacteria at a high concentration of the pigment. Ealier, Agematu et al. (2008) have reported that the violet pigment (deoxyviolacein and violacein) from Massilia sp. showed robust activity against
B. subtilis, E. coli and S. aureus. Lapenda et al. (2015) have reported that prodigiosin exhibited antimicrobial activities against different pathogens like E. coli, E. faecalis, S. pyogenes, Acinetobacter sp. P. aeruginosa and S. aureus. Mumtaz et al. (2019) have reported that prodigiosin from Chromobacterium prodgiosum showed antagonistic activity against Bacillus subtilis, Corynebacterium diphtheriae and Staphylococcus aureus. Prodigiosin from Neisseria spp., showed strong activity against fungal strains like Aspergillus sp., Candida sp., Trichoderma sp. (Wagh and Mane, 2017). Fariq et al. (2019) isolated three pigment producing colonies namely Aquisalibacillus elongates MB592, Salinococcus sesuvii MB597 and Halomonas aquamarina MB598 and have reported that the pigments showed excellent antimicrobial activity. Bisht et al. (2020) have testified that violacein and deoxyviolacein showed antimicrobial activity against pathogenic fungi, Rosellinia necatrix.

The carotenoids produced by Halomonas sp. exhibited antimicrobial activities against Klebsiella sp., $S$. aureus, P. aeruginosa, Escherichia coli and Streptococcus pyogenes (Ravikumar et al., 2016). Zerrad et al. (2014) showed that melanin from Pseudomonas balearica strain U7 possessed antimicrobial activity against phytopathogenic strains. Pyocyanin showed activity against urinary tract pathogens like $S$. aureus, $S$. saprophyticus, S. epidermidis, E. coli and C. freundii (Mohammed and Almahde, 2017). El-Shouny et al. (2011) have reported that pyocyanin showed activity against all Gram-positive bacteria and $C$. albicans. These bioactive compounds will provide promising future in biomedical research. However, when monitoring the antimicrobial activities of microbial pigments, sometimes researchers use non-pure pigments. Then the observed antimicrobial effect is not related to the pigment itself but to another compound and this factor has to be reckoned while designing such studies.

\section{Anticancer Activities}

The chemotherapy is still the customary treatment method for the most dreadful disease of cancer and this treatment is cytotoxic to normal cells which affects not only tumor development, but also worsens patient's recovery (Felisa et al., 2015; Ravin et al., 2017). Hence, there is an endless demand to develop cheaper, safer natural products in the treatment of cancer to challenge the dreadful human disease. Bacterial pigments seem to have huge potential as a source of anticancer compounds and deserve a comprehensive investigation (Srilekha et al., 2018). Prodigiosin, from Serratia marcescens induces apoptosis in human cancer cell lines, hematopoietic cancer cell lines (Jurkat, NSO and HL60) and human oral cancer HSC-2 cells. Campas et al. (2003) have reported that the cytotoxic effect of prodigiosin showed significant activity against B-cell chronic lymphocytic of leukemia patients. The pigment from Salinicoccus sp. was found to exhibit inhibitory action against the growth of human cancer cell lines for the development of anticancer drugs (Srilekha et al., 2018). Prodigiosin from Pseudoalteromonas sp. 1,020 exhibited cytotoxicity against U937 leukemia cells (Wang et al., 2012).

The risk of breast cancer was shown to be reduced by the novel compound from yellowish pigment produced by Rhodococcus maris (Elsayed et al., 2017). The red pigment from 
Athrobacter sp. G20 isolated from the Caspian Sea exhibited remarkable anticancer activity against esophageal cancer cell lines (Afra et al., 2017) and carotenoids from Kocuria sp. QWT-12 showed anticancer activity against breast cancer cell lines MCF-7 (Rezaeeyan et al., 2017) (IC50 of $1 \mathrm{mg} / \mathrm{ml}$ ) whereas carotenoids from Haloferax volcanii showed activity against human liver carcinoma cell lines HepG2 (53.52\%) (Sikkandar et al., 2013). Derivatives of anthraquinone from Alternaria sp. ZJ9-6B showed activity against human breast cancer cell lines (Huang et al., 2015).

Violacein has shown its anticancer efficiency in numerous cell lines and Melo et al. (2000) found that the violacein (IC50 5$12 \mu \mathrm{M}$ ) was highly cytotoxic to V79 fibroblasts. Uveal melanoma cell lines, 92.1 and OCM-1 are found to be sensitive to violacein (GI50 1.69-2.21 $\mu \mathrm{M}$ ) and these results demonstrate that the violacein induces apoptosis in cancer cells (Saraiva et al., 2004) which is significant for defense against the diseases and cancers (Walsh et al., 2008). Alshatwi et al. (2016) have reported that violacein induced apoptosis in human breast cancer cells through upregulation of TNF- $\alpha$ expression and the p53 dependent mitochondrial pathway. Venegas et al. (2019) have now reported that violacein induced activation of inflammatory response, signaling through MAPK pathway, cytokine-cytokine receptor interaction and toll-like receptor signaling in raw 264.7 cells. Violacein could bind to hTLR8 to imidazoquinoline compounds by in silico analysis.

The phycocyanin interacts with non-specific targets from membrane to nucleus and kills cancer cells that are resistant to chemotherapy (Silva et al., 2018). The pyocyanin inhibited HepG2 human hepatoma cell proliferation and apoptosis (Zhao et al., 2014). The mutant strain $P$. aeruginosa S300-8 produces potent pyocyanin and this compound inhibited the growth and apoptosis of pelvic rhabdomyosarcoma cells (Hall et al., 2016). The melanin pigment from Streptomyces glaucescens NEAE-H showed cytotoxic activity against HFB4 skin cancer cell line (ElNaggar and El-Ewasy, 2017). There is a constant demand to develop effective anticancer drugs and these bioactive pigments from bacteria appear to be the most promising sources for new drug discoveries.

\section{Antioxidant Activities}

Antioxidants play a significant role to humans in protecting against various infections and degenerative diseases by inhibiting and scavenging free radicals. Many synthetic antioxidants are used to retain oxidation process which have potential health hazards and researchers are focusing to screen alternative antioxidants from natural sources (Lee et al., 2014). Carotenoids extracted from Kocuria marina DAGII, thermophilic bacteria Meiothermus and Thermus strains exhibits potent antioxidant properties (Rezaeeyan et al., 2017). Correa-Llanten et al. (2012) isolated carotenoid producing Pedobacter from an Antarctic bacterium which showed excellent antioxidant capacity. The carotenoid (flexirubin) from Fontibacter flavus YUAB-SR-25 showed significant antioxidant activity and inhibited lipid peroxidation (Prabhu et al., 2013).

Antonisamy and Ignacimuthu (2010) have testified that violacein from $C$. violaceum protects against oxidative damage by defense mechanism. Pyomelanin from Burkholderia cenocepacia C5424 was capable of protecting cells from oxidative stress (Keith et al., 2007). Lycopene has applications in various food products like nutritional food, soups, cereals for breakfast, beverages, surimi, dairy products, chips, spreads, pastas, snacks, and sauces (Chandi and Gill, 2011). Lycopene suppresses tumor cell proliferation in MSF-7 tumor cells (Numan et al., 2018). Fiedor and Burda (2014) reported that $\beta$-carotene suppresses the adverse effect of free radicals in humans. Majumdar et al. (2019) explored the bacterial isolate, Planococcus sp. TRC1 as carotenoid pigment producer which showed appreciable antioxidant activity leading to industrial applicability and additionally its potential to bio remediate the paper mill pulp effluent. These results show that the pigments are prospective ones for eventual use in pharmaceutical and food applications.

\section{Anti-inflammatory and Anti-allergic Activities}

Inflammation is an immunological defense mechanism induced in response to mechanical injuries (Menichini et al., 2009; Mueller et al., 2010). Oxidative stress plays an important role in endothelial dysfunction (Schramm et al., 2012), lung disease (Paola-Rosanna and Salvatore, 2012), gastrointestinal dysfunction (Kim et al., 2012b) and atherosclerosis (Hulsmans et al., 2012). Lee et al. (2013a) reported that ankaflavin possessed anti-allergic activity in both lung cell line (A549) and lungs ovalbumin (OVA)-challenged mice. Radhakrishnan et al. (2016) studied the soil isolate from desert producing yellowish-orange pigment from Streptomyces sp. D25 which showed strong antioxidant activity. Srilekha et al. (2018) isolated a marine pigmented bacteria, Micrococcus sp. which has strong potential as anti-inflammatory and wound healing agent and this is influenced by the antibacterial property of the pigment. Egeland (2016) reported another carotenoid, fucoxanthin from cyanobacteria possessing its anti-cancer, anti-inflammatory and anti-obesity properties. Thus, the bioactive pigment showed strong wound healing property and could be a good source for anti-inflammatory compounds.

\section{POSSIBLE APPLICATIONS APART FROM COLORANTS AND PHARMACY}

Food industries are looking for substitutions to synthetic food colors such as sunset yellow, tartrazine, and quinoline yellow (Table 2). Zeaxanthin from Flavobacterium sp. is used as an additive in poultry feeds (Pasarin and Rovinaru, 2018). Sajilata et al. (2008) reported that fish and crustaceans convert zeaxanthin to red-colored pigment, astaxanthin, which enhanced desirable red coloration of the shells. These pigments are considered safe and approved by FDA (Neeraj et al., 2011). Riboflavin (vitamin B2) are used in beverages, instant desserts and ice creams.

Carotenoids play an important role as sunscreen by maintaining the quality of foods by protecting from intense sunlight (Tendulkar et al., 2018). The carotenoids like torulene and torularhodin are being investigated in detail by many researchers and Matz et al. (2004) reported that torularhodin 
TABLE 2 | Rainbow (VIBGYOR) colorants possible with bacterial pigments.

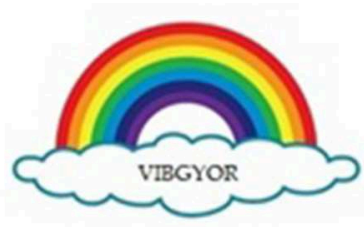

Synthetic colorants

Bacterial colorants

Food Applications

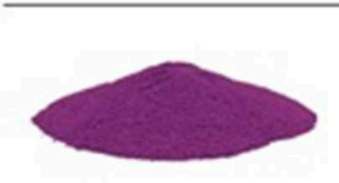

Reactive Violet -2

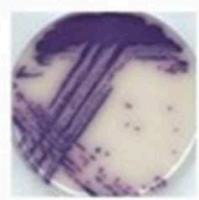

Chromobacterium violaceum
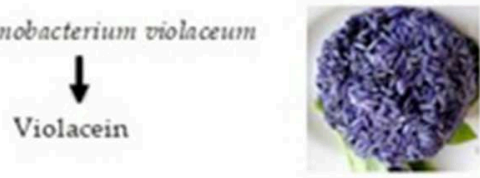

Purple food

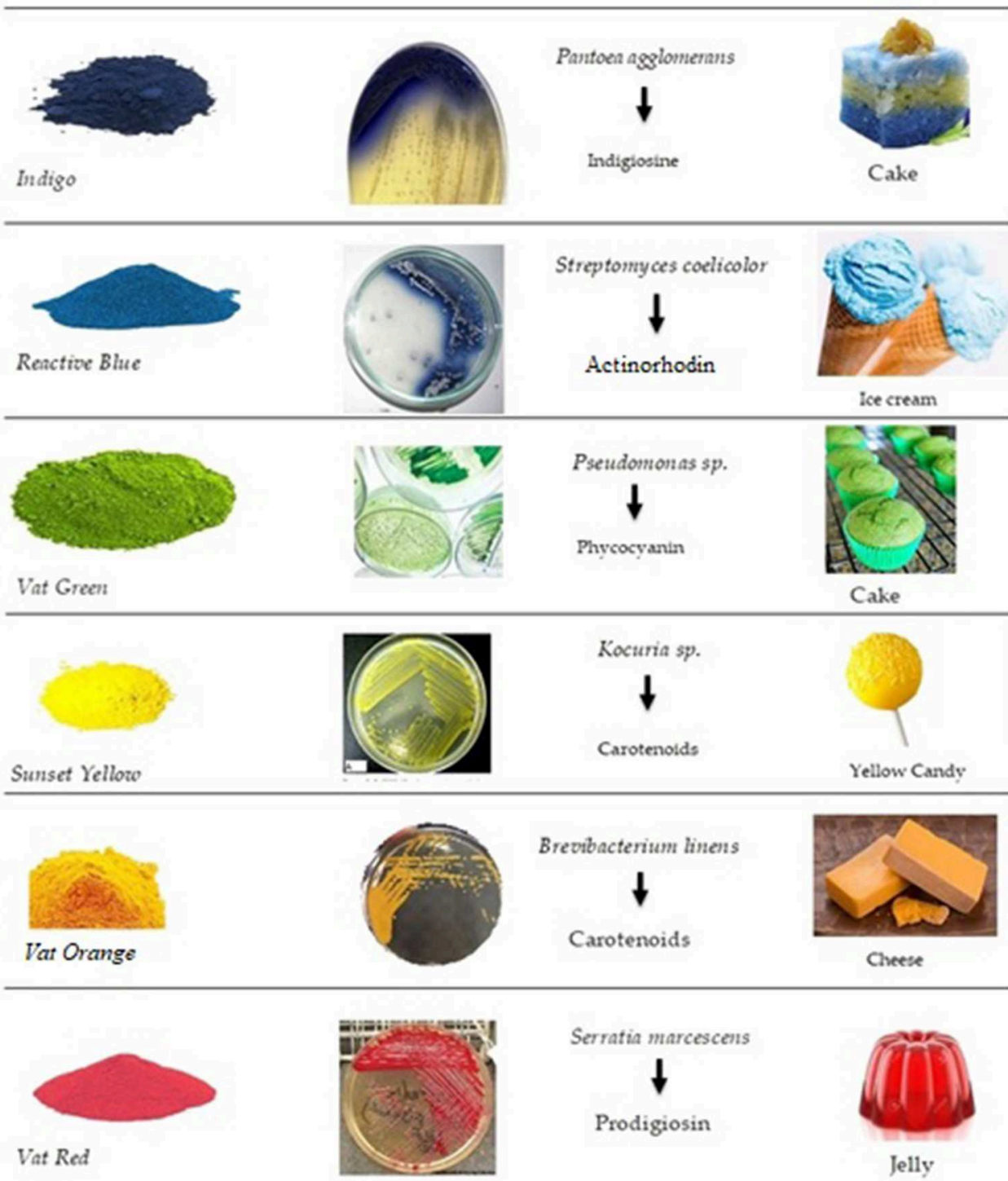

VIBGYOR (Violet-Indigo-Blue-Green-Yellow-Orange-Red) is a popular mnemonic device used for memorizing the traditional optical spectrum 
protects from oxidative stress. The concentration of aryl carotenoids from $B$. linens possessing antioxidant activity is not sufficient for commercialization at a competitive price and genetic modifications could be an alternative. Kurdziel and Solymosi (2017) reported that phycobiliproteins have great market value and they can be used as biochemical tags and food colorants due to their high color tone.

\section{STABILITY AND SOLUBILITY OF BACTERIAL PIGMENTS}

Though having great potential in terms of applications, natural colorants have only limited markets due to their poor stability. Sen et al. (2019) have now reported that various techniques are available to produce stable natural pigment with increased shelf life and market potential in a cost-effective manner. The most important distress among natural colorants is anthocyanin and because of its low stability, it has only restricted its use as natural colorants (Babaloo and Jamei, 2018).

Encapsulation plays an important role in maintaining the stability of pigments, thereby rising their shelf life. Physical and chemical attributes of food, stability during processing and storage and regulatory issues are the important criteria in selecting natural colorants for food applications (Sen et al., 2019). The value-added anthocyanin's stability would possibly give a chance in a multiplicity of food colorants. Beta-carotene possessing nutraceutical activity can be used as food colorants and is limited by solubility, stability, melting point and low bioavailability (Gutiérrez et al., 2013; Liang et al., 2013). $\beta$-carotene is quite unstable and degrades during food processing and storage (Mao et al., 2009). Therefore, to address the distresses of stability, encapsulation of $\beta$-carotene is carried out to enhance the stability for its application in food industry.

\section{Encapsulation}

Bacterial pigments are quite unstable at high temperatures, light, oxygen and hard to retain their characteristics when they are exposed to certain inherent conditions (Rao et al., 2017). Microencapsulation method is an alternative one to increase the stability and solubility which entraps the active components into the microparticles. The microencapsulation is packing any solid, liquid or gas in microparticles of size ranging from $\mathrm{mm}$ to $\mathrm{nm}$. The active compound, bacterial pigment becomes the core material and the packaging material is the wall material. The wall material should have low viscosity, emulsifying properties, biodegradable, low hygroscopicity as well as low cost (Barros and Stringheta, 2006). The wall materials used to encapsulate bacterial pigments include maltodextrins, modified starch, inulin, furcellaran etc. (Ozkan and Ersus, 2014). Encapsulated colorants have better solubility with improved stability to ambient conditions, leading to an increased shelf life. The wall material plays important roles by protecting the active material from light, temperature, humidity, oxygen as well as matrix interactions. The objective of encapsulating bacterial pigments for food industry applications include protecting core material, increasing shelf life and most importantly, controlling the release of pigment and suppressing any type of aroma. There are various reports available for encapsulating bacterial pigments viz., encapsulation of anthocyanin by spray drying in which maltodextrin has been used as the wall material (Silva et al., 2013), encapsulation of $\beta$-carotene by freeze drying using modified starch as wall material (Spada et al., 2012). These encapsulated powders have been applied in cakes, yogurt, soft drinks and found to be stable and effective (Rocha et al., 2012).

Under specific conditions, the encapsulated material can be protected and released in a controlled way to widen its scope in food applications (Rosas et al., 2017). Bacterial pigments because of their bioactive components can be used as food colorants and in the pharma industry (Venil et al., 2015) and the stability of the pigment may be affected by several factors, such as temperature, light, $\mathrm{pH}$, oxygen, etc. The above said factors directed researchers to search for inexpensive processes aimed at increasing the shelf life and stability of bacterial pigments (Venil et al., 2016).

The stability of these bioactive bacterial pigments can be improved using the encapsulation technique which entraps a sensitive ingredient inside the coating material. The flexirubin from Chryseobacterium artocarpi CECT8497 showed that microencapsulation increased the stability by giving great protection to flexirubin compared to its free form. Moreover, the antioxidant activity is higher for microcapsules and the boosted properties indicate that this colorants from C. artocarpi CECT8497 can be used as natural colorants in food industry (Venil et al., 2016). Namazkar et al. (2013) reported that nonencapsulated prodigiosin from Serratia marcescen has poor stability on exposure to light, $\mathrm{pH}$ and temperature whereas the encapsulated prodigosin increases the stability and solubility and it can be used as an alternative to existing synthetic colorants.

\section{Nano-Emulsion}

Nano-emulsions are droplet size of $100 \mathrm{~nm}$ or even less and can be prepared to encapsulate bacterial pigments. It contains water, oil and emulsifier and the addition of emulsifier is the most crucial step in the formation of nano-emulsions which decrease the tension between water and oil phases. Most commonly used emulsifiers are surfactants but proteins and lipids can also be used. Compared to micro or macro emulsions, nanoemulsions have improved applications due to its large surface area, kinetic stability and resistance to physical or chemical change (Gupta et al., 2016). These nano-emulsions for food colorants possess various advantages like non-irritant and nontoxic, making them suitable for applications in food industry. Nano-emulsions stabilize the colorants within the emulsion and has no undesired taste (Jaiswal et al., 2015). Nano-emulsion can also decrease the amount of colorant required to obtain the desired color and hence it is a cost-effective method. The formation and stability of nano-emulsion with $\beta$-carotene were reported and stabilized using $\beta$-lactoglobulin, a biocompatible emulsifier (Yi et al., 2014). Several methods for encapsulation of $\beta$-carotene in suitable delivery system, such as nano-emulsion, micro-emulsion, liposome, solid lipid nanoparticles and complex assemblies with macromolecules are reported with increased bioavailability and so there is a scope for further research in this 
field (Cornacchia and Roos, 2011; Qian et al., 2012; Liang et al., 2013; Donhowe et al., 2014).

\section{FUTURE PERSPECTIVES AND CONCLUSIONS}

Natural colorants are being extracted from microorganisms and are used for various applications. Of them, pigments extracted from bacterial sources are noteworthy and have better prospective applications due to their easy and cost-effective production processes. Many bacteria produce different shades of coloring pigments prospective to meet the emerging market needs and industrial applications. Pigments extracted from the trustworthy strains of bacteria have exhibited their diversified activities like anti-microbial, anti-cancer, anti-oxidant, antiinflammatory and anti-allergic activities and thus exposing their potential for medicinal applications. Further, the bacterial pigments have exhibited their potential applications in food, agriculture and other industries too. To enhance the stability and shelf life of the pigments, strategies of encapsulation and nano-emulsions have been tried and their effectiveness testified.

Yet comparing to the emerging global market needs, the volume of bacterial pigment production is less. There is a better scope to upgrade their overall production volume so as to meet the market demands by applying various biotechnological tools. In this aspect, genetic engineering to strain improvement, genome shuffling, fermentation strategies to scale-up production

\section{REFERENCES}

Afra, S., Makhdoumi, A., Matin, M. M., and Feizy, J. (2017). A novel red pigment from marine Arthrobacter sp. G20 with specific anticancer activity. J. Appl. Microbiol. 123, 1228-1236. doi: 10.1111/jam.13576

Agematu, H., Suzuki, K., and Tsuya, H. (2008). Massilia sp. BS-1, a novel violacein producing bacterium isolated from soil. Biosci. Biotechnol. Biochem. 75, 2008-2010. doi: 10.1271/bbb.100729

Ahmetagic, A., and Pemberton, J. M. (2010). Stable high level expression of the violacein indolocarbazole anti-tumour gene cluster and the Streptomyces lividans amyA gene in E. coli K12. Plasmid 63, 79-85. doi: 10.1016/j.plasmid.2009.11.004

Ajikumar, P. K., Xiao, W. H., Tyo, K. E., Wang, Y., Simeon, F., Leonard, E., et al. (2010). Isoprenoid pathway optimization for Taxol precursor overproduction in Escherichia coli. Science 330, 70-74. doi: 10.1126/science.1191652

Alper, H., Miyaoku, K., and Stephanopoulos, G. (2005). Construction of lycopeneoverproducing E. coli strains by combining systematic and combinatorial gene knockout targets. Nat. Biotechnol. 23, 612-616. doi: 10.1038/nbt1083

Alshatwi, A. A., Subash-Babu, P., and Antonisamy, P. (2016). Violacein induces apoptosis in human breast cancer cells through up regulation of BAX, p53 and down regulation of MDM2. Exp. Toxicol. Pathol. 68, 89-97. doi: 10.1016/j.etp.2015.10.002

Ambati, R. R., Phang, S. M., Ravi, S., and Aswathanarayana, R. G. (2014). Astaxanthin: sources, extraction, stability, biological activities and its commercial applications - a review. Mar. Drugs 12, 128-152. doi: $10.3390 / \mathrm{md} 12010128$

Antonisamy, P., and Ignacimuthu, S. (2010). Immunomodulatory, analgesic and antipyretic effects of violacein isolated from Chromobacterium violaceum. Phytomedicine 17, 300-304. doi: 10.1016/j.phymed.2009.05.018

Arseneault, T., Goyer, C., and Filion, M. (2013). Phenazine production by Pseudomonas sp. LBUM223 contributes to the biological to industry level etc. play vital roles for maximum production of bacterial pigments at cheap cost with high stability. As the market for bacterial pigment products is globally large for eventual applications, ecofriendly and economic bacterial pigment production has a better prospective.

\section{AUTHOR CONTRIBUTIONS}

$\mathrm{CV}$ : conceptualization, original draft preparation, and writing. LD: writing, review, and editing. PR: review. All authors contributed to the article and approved the submitted version.

\section{FUNDING}

This work was supported and funded by the University Grants Commission (UGC), New Delhi under the Dr. D. S. Kothari Postdoctoral Fellowship (BL/17-18/0479) dated 25th September 2018.

\section{ACKNOWLEDGMENTS}

CV thanks the UGC for awarding the Dr. D. S. Kothari Postdoctoral Fellowship (BL/17-18/0479). Also, the authors thank Anna University, Regional Campus - Coimbatore for providing necessary facilities to carry out the project work. LD deeply thanks the Conseil Régional de La Réunion, Réunion island, Indian Ocean, for continuous financial support of research activities dedicated to microbial pigments.

control of potato common scab. Phytopathology 103, 995-1000. doi: 10.1094/PHYTO-01-13-0022-R

Aruldass, C. A., Dufossé, L., and Ahmad, W. A. (2018). Current perspective of yellowishorange pigments from microorganisms-a review. J. Clean. Prod. 180, 168-182. doi: 10.1016/j.jclepro.2018.01.093

Ayuningrum, D., Kristiana, R., Asagabaldan, M. A., Sabdono, A., Radjasa, O. K., Nuryadi,H., et al. (2017). Isolation, characterization and antagonistic activity of bacterial symbionts hard coral Pavona sp. isolated from Panjang Island, Jepara against infectious multi-drug resistant (MDR) bacteria. IOP Conf. Ser. Earth. Environ. Sci. 55:012029. doi: 10.1088/1755-1315/55/1/012029

Babaloo, F., and Jamei, R. (2018). Anthocyanin pigment stability of Cornus mas Macrocarpa under treatment with $\mathrm{pH}$ and some organic acids. Food Sci. Nutr. 6, 168-173. doi: 10.1002/fsn3.542

Banerjee, D., Chatterjee, S., Banerjee, U. C., Guha, A. K., and Ray, L. (2011). Green pigment from Bacillus cereus M16 (MTCC 5521): production parameters and antibacterial activity. Appl. Biochem. Biotechnol. 164, 767-779. doi: 10.1007/s12010-011-9172-8

Banerjee, D., Mondal, A., Gupta, M., Guha, A. K., and Ray, L. (2013). Optimization of fermentation conditions for green pigment production from Bacillus cereus M116 (MTCC 5521) and its pharmacological application. Lett. Appl. Microbiol. 58, 25-30. doi: 10.1111/lam.12151

Barros, F., and Stringheta, P. (2006). Microencapsulamento de antocianinas - Uma alternativa para o aumento de sua aplicabilidade como ingrediente alimentício. Biotechnol. Ciencia. Des. 36, 18-24.

Berry, A., Janssens, D., Humbelin, M., Jore, J. P. M., Hoste, B., Cleenwerck, I., et al. (2003). Paracoccus zeaxanthinifaciens sp. nov. a zeaxanthin producing bacterium. Int. J. Syst. Evol. Microbiol. 53, 231-238. doi: 10.1099/ijs.0. 02368-0

Bhosale, P. B., and Gadre, R. V. (2001). Production of beta-carotene by a mutant of Rhodotorula glutinis. Appl. Microbiol. Biotechnol. 55, 423-427. doi: $10.1007 / \mathrm{s} 002530000570$ 
Biot-Pelletier, D., and Martin, V. J. (2014). Evolutionary engineering by genome shuffling. Appl. Microbiol. Biotechnol. 98, 3877-3887. doi: 10.1007/s00253-014-5616-8

Bisht, G., Srivastava, S., Kulshreshtha, R., Sourirajan, A., Baumler, D., and Dev, K. (2020). Applications of red pigments from psychrophilic Rhodonellum psychrophilum GL8 in health, food and antimicrobial finishes on textiles. Process Biochem. 94, 15-29. doi: 10.1016/j.procbio.2020. 03.021

Calegari-Santos, R., Diogo, R. A., Fontana, J. D., and Bonfim, T. M. B. (2016). Carotenoid production by halophilic archaea under different culture conditions. Curr. Microbiol. 72, 641-651. doi: 10.1007/s00284-015-0974-8

Campas, C., Dalmau, M., Montaner, B., Barragan, M., Bellosillo, B., Colomer, D., et al. (2003). Prodigiosin induces apoptosis of B and T cells from B cell chronic lymphocytic leukemia. Leukemia 17, 46-50. doi: 10.1038/sj.leu.2402860

Center for Diseases Control and Prevention (2018). Biggest Threats. Available online at: https://www.cdc.gov/drugresistance/biggest_threats.html (accessed July 5, 2020)

Chandi, G. K., and Gill, B. S. (2011). Production and characterization of microbial carotenoids as an alternative to synthetic colors: a review. Int. J. Food Prop. 4, 503-513. doi: 10.1080/10942910903256956

Chiba, S., Tsuyoshi, N., Fudou, R., Ojika, M., Murakami, Y., Ogoma, Y., et al. (2006). Magenta pigment produced by fungus. J. Gen. Appl. Microbiol. 52, 201-207. doi: 10.2323/jgam.52.201

Choi, E. J., Nam, S. J., Paul, L., Beatty, D., Kauffman, C. A., Jensen, P. R., et al. (2015). Previously uncultured marine bacteria linked to novel alkaloid production. Chem. Biol. 22, 1270-1279. doi: 10.1016/j.chembiol.2015. 07.014

Choi, H. S., Lee, S. Y., Kim, T. Y., and Woo, H. M. (2010). In silico identification of gene amplification targets for improvement of lycopene production. Appl. Environ. Microbiol. 76, 3097-3105. doi: 10.1128/AEM.00115-10

Choi, S. Y., Kim, S., Lyuck, S., Kim, S. B., and Mitchell, R. J. (2015a). Highlevel production of violacein by the newly isolated Duganella violaceinigra str.NI28 and its impact on Staphylococcus aureus. Sci. Rep. 5:15598. doi: 10.1038/srep15598

Choi, S. Y., Yoon, K. H., Lee, J. I., and Mitchell, R. J. (2015b). Violacein: properties and production of versatile bacterial pigment. Biomed. Res. Int. 2015:465056. doi: 10.1155/2015/465056

Chu, M. K., Lin, L. F., Twu, C. S., Lin, R. H., Lin, Y. C., Hsu, S. T., et al. (2010). Unique features of Erwinia chrysanthemi (Dickeya dadantii) RA3B genes involved in the blue indigiodine production. Microbiol. Res. 165, 483-495. doi: 10.1016/j.micres.2009.09.004

Clauditz, A., Resch, A., Wieland, K. P., Peschel, A., and Götz, F. (2006). Staphyloxanthin plays a role in the fitness of Staphylococcus aureus and its ability to cope with oxidative stress. Infect. Immun. 74, 4950-4953. doi: 10.1128/IAI.00204-06

Cornacchia, L., and Roos, Y. H. (2011). Stability of $\beta$-carotene in proteinstabilized oil-in-water delivery systems. J. Agric. Food Chem. 59, 7013-7020. doi: 10.1021/jf200841k

Correa-Llanten, D. N., Amenabar, M. J., and Blamey, J. M. (2012). Antioxidant capacity of novel pigments from an Antarctic bacterium. J. Microbiol. 50, 374-379. doi: 10.1007/s12275-012-2029-1

Deinove (2019). Carotenoids Market. Natural Carotenoids Meeting Consumer Needs. Available online at: http://www.deinove.com/en/profile/strategy-andmarkets/carotenoids-market/ (accessed April 2, 2020).

Deorukhkar, A. A., Chander, R., Ghosh, S. B., and Sainis, K. B. (2007). Identification of a red-pigmented bacterium producing a potent antitumor N- alkylated prodigiosin as Serratia marcescens. Res. Microbiol. 158, 399-404. doi: 10.1016/j.resmic.2007.02.010

Deparis, Q., Claes, A., Moreno, M. R. F., and Thevelein, J. M. (2017). Engineering tolerance to industrially relevant stress factors in yeast cell factories. FEMS Yeast Res. 17:36. doi: 10.1093/femsyr/fox036

Dharmaraj, S., Ashokkumar, B., and Dhevendaran, K. (2009). Fermentative production of carotenoids from marine actinomycetes. Iran J. Microbiol. $1,36-41$.

Donhowe, E. G., Flores, F. P., Kerr, W. L., Wicker, L., and Kong, F. (2014). Characterization and in vitro bioavailability of $\beta$-carotene: effects of microencapsulation method and food matrix. LWT Food Sci. Technol. 57, 42-48. doi: 10.1016/j.lwt.2013.12.037
Du, K. L., and Swamy, M. N. S. (2016). Particle Swarm Optimization. Search and Optimization by Metaheuristics. Springer International Publishing. 153-173. doi: 10.1007/978-3-319-41192-7_9

Dufossé, L. (2018). "Microbial pigments from bacteria, yeasts, fungi and microalgae for the food and feed industries," in Handbook of food bioengineering, Multi volume set (I-XX), 1st Edn, Vol. VII, Natural and Artificial Flavoring Agents and Food Dyes, eds A. M. Grumezescu and A. M. Holban (Oxford: Academic Press Publisher), 113-132. doi: 10.1016/B978-0-12-811518-3.00004-1

Dufossé, L., Galaup, P., Yaron, A., Arad, S. M., Blanc, P., Murthy, K. N. C., et al. (2005). Microorganisms and microalgae as source of pigments for use: a scientific oddity or an industrial reality? Trend. Food Sci. Technol. 16, 389-406. doi: 10.1016/j.tifs.2005.02.006

Dufossé, L. (2006). Microbial production of food grade pigments. Food Technol. Biotechnol. 44, 313-323.

Duran, M., Ponezi, A. N., Faljoni-Alario, A., Teixeira, M. F., Justo, G. J., and Duran, N. (2012). Potential applications of violacein: a microbial pigment. Med. Chem. Res. 21, 1524-1532. doi: 10.1007/s00044-011-9654-9

Durán, N., and Menck, C. F. M. (2001). Chromobacterium violaceum: a review of pharmacological and industrial perspectives. Crit. Rev. Microbiol. 27, 201-222. doi: 10.1080/20014091096747

Egeland, E. S. (2016). "Carotenoids". in The Physiology of Microalgae: Developments in Applied Phycology. eds M. A. Borowitzka, J. Beardall, J. A. Raven (Switzerland: Springer, Cham), 507-563.

El-Naggar, N. A., and El-Ewasy, S. M. (2017). Bioproduction, characterization, anticancer and antioxidant activities of extracellular melanin pigment produced by newly isolated microbial cell factories Streptomyces glaucescens NEAE-H. Sci. Rep. 7:42129. doi: 10.1038/srep42129

Elsayed, Y., Refaat, J., Abdelmohsen, U. R., and Fouad, M. A. (2017). The genus Rhodococcus as a source of novel bioactive substances: a review. J. Pharmacog. Phytochem. 6, 83-92.

El-Shouny, W. A., Al-Baidani, A. R. H., and Hamza, W. T. (2011). Antimicrobial activity of pyocyanin produced by Pseudomonas aeruginosa isolated from surgical wound infections. Int. J. Pharm. Med. Sci. 1, 1-7.

Fariq, A., Yasmin, A., and Jamil, M. (2019). Production, characterization and antimicrobial activities of bio-pigments by Aquisalibacillus elongatus MB592, Salinicoccus sesuvii MB597, and Halomonas aquamarina MB598 isolated from Khewra Salt Range, Pakistan. Extremophiles 23, 1095-1107. doi: 10.1007/s00792-019-01095-7

Farmer, W. R., and Liao, J. C. (2001). Precursor balancing for metabolic engineering of lycopene production in Escherichia coli. Biotechnol. Prog. 17, 57-61. doi: 10.1021/bp000137t

Feher, D., Barlow, R. S., Lorenzo, P. S., and Hemscheidt, T. (2008). A 2-substituted prodiginine, 2-(p-hydroxybenzyl)prodigiosin, from Pseudoalteromonas rubra. J. Nat. Prod. 71, 1970-1972. doi: 10.1021/np800493p

Felisa, P., Nisha, K., Hyacinth, H., and Linz, B. G. (2015). In vitro antioxidant and anticancer activity of Mimosa pudica Linn extract and L-mimosine on lymphoma daudi cells. Int. J. Pharm. Sci. 12, 100-104.

Fernandez-Orozco, R., Roca, M., Gandul-Rojas, B., and Gallardo-Guerrero, L. (2011). DPPH-scavenging capacity of chloroplastic pigments and phenolic compounds of olive fruits (cv. Arbequina) during ripening. J. Food Comp. Anal. 24, 858-864. doi: 10.1016/j.jfca.2011.05.003

Fiedor, J., and Burda, K. (2014). Potential role of carotenoids as antioxidants in human health and disease. Nutrients 6, 466-488. doi: 10.3390/nu6020466

George, Y. L., and Nizet, V. (2009). Color me bad: microbial pigments as virulence factors. Trend. Microbiol. 17, 406-413. doi: 10.1016/j.tim.2009.06.006

Gupta, A., Eral, H. B., Hatton, T. A., and Doyle, P. S. (2016). Nanoemulsions: formation, properties and applications. Soft Matter. 12, 2826-2841. doi: 10.1039/C5SM02958A

Gutiérrez, F. J., Albillos, S. M., Casas-Sanz, E., Cruz, Z., GarcíaEstrada, C., García-Guerra, A., et al. (2013). Methods for the nanoencapsulation of $\beta$-carotene in the food sector. Trend. Food Sci. Technol. 32, 73-83. doi: 10.1016/j.tifs.2013.05.007

Hall, S., McDermott, C., Anoopkumar-Dukie, S., McFarland, A. J., Perkins, A. V., Davey, A. K., et al. (2016). Cellular effects of pyocyanin, a secreted virulence factor of Pseudomonas aeruginosa. Toxins 8:236. doi: 10.3390/toxins 8080236

Heider, S. A., Peters-Wendisch, P., Wendisch, V. F., Beekwilder, J., and Brautaset, T. (2014). Metabolic engineering for the microbial production of carotenoids 
and related products with a focus on the rare C50 carotenoids. Appl. Microbiol. Biotechnol. 98, 4355-4368. doi: 10.1007/s00253-014-5693-8

Henke, N. A., Wiebe, D., Pérez-García, F., Peters-Wendisch, P., and Wendisch, V. F. (2018). Coproduction of cell-bound and secreted value-added compounds: Simultaneous production of carotenoids and amino acids by Corynebacterium glutamicum. Bioresour. Technol. 247, 744-752. doi: 10.1016/j.biortech.2017.09.167

Huang, C. H., Pan, J. H., Chen, B., Yu, M., Huang, H. B., Zhu, X., et al. (2015). Three bianthraquinone derivatives from the mangrove endophytic fungus Alternaria sp. ZJ9-6B from the South China Sea. Mar. Drugs 9, 832-843. doi: $10.3390 / \mathrm{md} 9050832$

Hulsmans, M., van Dooren, E., and Holvoet, P. (2012). Mitochondrial reactive oxygen species and risk of atherosclerosis. Curr. Atherosclerosis Rep.14, 264-276. doi: 10.1007/s11883-012-0237-0

Jaiswal, M., Dudhe, R., and Sharma, P. K. (2015). Nanoemulsion: an advanced mode of drug delivery system. Biotech 5, 123-127. doi: 10.1007/s13205-014-0214-0

Jamali, S., Alizadeh, F., and Sadeqi, S. (2016). "Task scheduling in cloud computing using particle swarm optimization," in 9th International Conference, ISUM 2018, Mexico, eds M. Torres, J. Klapp, I. Gitler, and A. Tchernykh, 192.

Jayaseelan, S., Ramaswamy, D., and Dharmaraj, S. (2014). Pyocyanin: production, applications, challenges and new insights. World J. Microbiol. Biotechnol. 30, 1159-1168. doi: 10.1007/s11274-013-1552-5

Jinendiran, S., Kumar, B. S. D., Dahms, H. U., Arulanandam, C. D., and Sivakumar, N. (2019). Optimization of submerged fermentation process for improved production of beta carotene by Exiguobacterium acetylicum S01. Heliyon 5:e01730. doi: 10.1016/j.heliyon.2019.e01730

Jothi, N. (2016). "Prediction of generalized anxiety disorder using particle swarm optimization," in Advances in Information and Communication Technology: Proceedings of the International Conference, ICTA 2016. Springer. 538:480. doi: 10.1007/978-3-319-49073-1_52

Kalinovskaya, N. I., Romanenko, L. A., and Kalinovsky, A. I. (2017). Antibacterial low-molecular-weight compounds produced by the marine bacterium Rheinheimera japonica KMM 9513T. Antonie Leeuwenhoek 110, 719-726. doi: 10.1007/s10482-017-0839-1

Keith, K. E., Killip, L., He, P., Moran, G. R., and Valvano, M. A. (2007). Burkholderia cenocepacia C5424 produces a pigment with antioxidant properties using a homogentisate intermediate. J. Bacteriol. 189, 9057-9065. doi: 10.1128/JB.00436-07

Kim, D., Kim, J. F., Yim, J. H., Kwon, S. K., and Lee, C. H. (2008). Red to red - the marine bacterium Hahella chejuensis and its product prodigiosin for mitigation of harmful algal blooms. J. Microbiol. Biotechnol. 18, 1621-1629.

Kim, H. W., Kim, J. B., Cho, S. M., Chung, M. N., Lee, Y. M., and Chu, S. M. (2012a). Anthocyanin changes in the Korean purple-fleshed sweet potato, Shinzami, as affected by steaming and baking. Food Chem. 130, 966-972. doi: 10.1016/j.foodchem.2011.08.031

Kim, M. J., Lim, J., Seo, J. H., and Jung, H. K. (2011). Hybrid optimization strategy using response surface methodology and genetic algorithm for reducing cogging torque of SPM. J. Elec. Eng. Technol. 6, 202-207. doi: 10.5370/JEET.2011.6.2.202

Kim, Y. J., Kim, E. H., and Hahm, K. B. (2012b). Oxidative stress in inflammationbased gastrointestinal tract diseases: challenges and opportunities. J. Gastroenterol. Hepatol. 27, 1004-1010. doi: 10.1111/j.1440-1746.2012. 07108.x

Kirti, K., Amita, S., Priti, S., Kumar, A. M., and Jyoti, S. (2014). Colorful world of microbes: carotenoids and their applications. Adv. Biol. 2016:837891. doi: $10.1155 / 2014 / 837891$

Korumilli, T., and Mishra, S. (2014). Carotenoid production by Rhodotorula sp. on fruit waste extract as a sole carbon source and optimization of key parameters. Iran J. Chem. Eng. 33, 89-99.

Kothari, V., Sharma, S., and Padia, D. (2017). Recent research advances on Chromobacterium violaceum. Asia. Pac. J. Trop. Med. 10, 744-752. doi: 10.1016/j.apjtm.2017.07.022

Kumar, A., Vishwakarma, H. S., and Singh, J. (2015). Microbial pigments: production and their applications in various industries. IJPCBS 5, 203-212.

Kumar, R. R., and Prasad, S. (2011). Metabolic engineering of bacteria. Ind. J. Microbiol. 51, 403-409. doi: 10.1007/s12088-011-0172-8
Kurdziel, M. B., and Solymosi, K. (2017). Phycobilins and phycobiliproteins used in food industry and medicine. Mini Rev. Med. Chem. 17, 1173-1193. doi: $10.2174 / 1389557516666160912180155$

Lange, B. M., Rujan, T., Martin, W., and Croteau, R. (2000). Isoprenoid biosynthesis: the evolution of two ancient and distinct pathways across genomes. Proc. Natl. Acad. Sci. U.S.A. 97, 13172-13177. doi: $10.1073 /$ pnas. 240454797

Lapenda, J. C., Silva, P. A., Vicalvi, M. C., Sena, K. X., and Nascimento, S. C. (2015). Antimicrobial activity of prodigiosin isolated from Serratia marcescens UFPEDA 398. World J. Microbiol. Biotechnol. 31, 399-406. doi: 10.1007/s11274-014-1793-y

Lara, A. R., Galindo, E., Ramirez, O. T., and Palomares, L. A. (2006). Living with heterogeneities in bioreactors: understanding the effects of environmental gradients on cells. Mol. Biotechnol. 34, 355-381. doi: 10.1385/MB:34:3:355

Lazaro, J. E., Nitcheu, J., Predicala, R. Z., Mangalindan, G. C., Nesslany, F., Marzin, D., et al. (2002). Heptyl prodigiosin, a bacterial metabolite, is antimalarial in vivo andnon-mutagenic in vitro. J. Nat. Toxins. 11,367-377.

Lee, C. L., Wen, J. Y., Hsu, Y. W., and Pan, T. M. (2013a). Monascus fermented yellow pigments monascin and ankaflavin showed antiobesity effect via the suppression of differentiation and lipogenesis in obese rats fed a high fat diet. $J$. Agric. Food Chem. 61, 1493-1500. doi: 10.1021/jf304015z

Lee, D. R., Lee, S. K., Cho, B. K., Cheng, J., Lee, Y. S., Yang, S. H., et al. (2014). Antioxidant activity and free radical scavenging activities of Streptomyces sp. strain MJM 10778. Asian Pac. J. Trop. Med. 7, 962-967. doi: 10.1016/S1995-7645(14)60170-X

Lee, M. E., Aswani, A., Han, A. S., Tomlin, C. J., and Dueber, J. E. (2013b). Expression level optimization of a multi enzyme pathway in the absence of a high throughput assay. Nucleic Acid. Res. 41, 10668-10678. doi: 10.1093/nar/gkt809

Li, D., Liu, J., Wang, X., Kong, D., Du, W., Li, H., et al. (2018). Biological potential and mechanism of prodigiosin from Serratia marcescens subsp. lawsoniana in human choriocarcinoma and prostate cancer cell lines. Int. J. Mol. Sci. 19:3465. doi: $10.3390 /$ ijms 19113465

Liang, R., Huang, Q., Ma, J., Shoemaker, C. F., and Zhong, F. (2013). Effect of relative humidity on the store stability of spraydried beta carotene nanoemulsions. Food Hydrocoll. 33, 225-233 doi: 10.1016/j.foodhyd.2013.03.015

Lim, S. H., Choi, J. S., and Park, E. Y. (2001). Microbial production of riboflavin using riboflavin overproducers, Ashbya gossypii, Bacillus subtilis and candida famate: an overview. Biotechnol. Bioproc. Eng. 6, 75-88. doi: 10.1007/BF02931951

Liu, G. Y., Essex, A., Buchanan, J. T., Datta, V., Hoffman, H. M., Bastian, J. F., et al. (2005a). Staphylococcus aureus golden pigment impairs neutrophil killing and promotes virulence through its antioxidant activity. J. Exp. Med. 202, 209-215. doi: $10.1084 / \mathrm{jem} .20050846$

Liu, J., Guan, X., Zhu, D., and Sun, J. (2008). Optimization of the enzymatic pretreatment in oat bran protein extraction by particle swarm optimization algorithms for response surface modeling. LWT Food Sci. Technol. 41, 1913-1918. doi: 10.1016/j.lwt.2008.02.013

Liu, R., Cui, C. B., Duan, L., Gu, Q. Q., and Zhu, W. M. (2005b). Potent in vitro anticancer activity of metacycloprodigiosin and undecylprodigiosin from a sponge-derived actinomycete Saccharopolyspora sp. nov. Arch. Pharm. Res. 28, 1341-1344. doi: 10.1007/BF02977899

Long, T. V. (2004). Process for production of carotenoids, xanthophylls and apocarotenoids utilizing eukaryotic microorganisms. US Patent 6783951.

Magocha, T. A., Zabed, H., Yang, M., Yun, J., Zhang, H., and Qi, X. (2018). Improvement of industrially important microbial strains by genome shuffling: current status and future prospects. Bioresour. Technol. 257, 281-289. doi: 10.1016/j.biortech.2018.02.118

Majumdar, S., Priyadarshinee, R., Kumar, A., Mandal, T., and Mandal, D. D. (2019). Exploring Planococcus sp. TRC1, a bacterial isolate, for carotenoid pigment production and detoxification of paper mill effluent in immobilized fluidized bed reactor. J. Clean. Prod. 211, 1389-1402. doi: 10.1016/j.jclepro.2018.11.157

Malik, K., Tokkas, J., and Goyal, S. (2012). Microbial pigments: a review. Int. J. Microb. Res. Technol. 361-365.

Mao, L. K., Xu, D. X., Yang, J., Yuan, F., Gao, X. Y., and Zhao, J. (2009). Effect of small and large molecule emulsifiers on the characteristics of beta-carotene 
nanoemulsions prepared by high pressure homogenization. Food Technol. Biotechnol. 47, 336-342.

Market Research Report (2016). Carotenoids Market by type (astaxanthin, betacarotene, canthaxanthin, lutein, lycopene, \& zeaxanthin), source (synthetic and natural), application (supplements, food, feed, and cosmetics), \& by Region Global Trends \& Forecasts to 2021.

Matz, C., Deines, P., Boenigk, J., Arndt, H., Eberl, L., Kjelleberg, S., et al. (2004). Impact of violacein-producing bacteria on survival and feeding of bacterivorous nanoflagellates. Appl. Environ. Microbiol. 70, 1593-1599. doi: 10.1128/AEM.70.3.1593-1599.2004

Mavrodi, D. V., Bonsall, R. F., Delaney, S. M., Soule, M. J., Phillips, G., and Thomashow, L. S. (2001). Function analysis of genes for biosynthesis of pyocyanin and phenazine-1-carboxamide from Pseudomonas aeruginosa PAO1. J. Bacteriol. 183, 6454-6465. doi: 10.1128/JB.183.21.6454-6465.2001

Melo, P. S., Engler, S. S. M., Vidal, B. C., Haun, M., and Duran, N. (2000). Violacein cytotoxicity and induction of apoptosis in V79 cells. In vitro cell. Devl. Biol. 36, 539-543. doi: 10.1290/1071-2690(2000)036<0539:vcaioa > 2.0.co;2

Melvin, M. S., Tomlinson, J. T., Saluta, G. R., Kucera, G. L., Lindquist, N., and Manderville, R. A. (2000). Double-strand DNA cleavage by copper prodigiosin. J. Am. Chem. Soc. 122, 6333-6334. doi: 10.1021/ja0000798

Menichini, F., Tundis, R., Bonesi, M., Loizzo, M. R., Conforti, F., Statti, G., et al. (2009). The influence of fruit ripening on the phytochemical content and biological activity of capsicum chinense Jacq. cv Habanero. Food Chem. 114, 553-560. doi: 10.1016/j.foodchem.2008.09.086

Mohammed, E. T., Wang, S., Lennen, R. M., Herrgard, M. J., Simmons, B. A., Singer, S. W., et al. (2017). Generation of a platform strain for ionic liquid tolerance using adaptive laboratory evolution. Microb. Cell Fact. 16, 204. doi: 10.1186/s12934-017-0819-1

Mohammed, T. A., and Almahde, M. A. M. (2017). Antimicrobial activity of pyocyanin for inhibition of Pseudomonas aeruginosa urinary tract pathogens. Asian J. Med. Heal. 4, 1-9. doi: 10.9734/AJMAH/2017/33379

Mueller, M., Hobiger, S., and Jungbauer, A. (2010). Anti-inflammatory activity of extracts from fruits, herbs and spices. Food Chem. 122, 987-996. doi: 10.1016/j.foodchem.2010.03.041

Mukhopadhyay, A. (2015). Tolerance engineering in bacteria for the production of advanced biofuels and chemicals. Trend. Microbiol. 23, 498-508. doi: 10.1016/j.tim.2015.04.008

Mumtaz, R., Bashir, S., Numan, M., Shinwari, Z. K., and Ali, M. (2019). Pigments from soil bacteria and their therapeutic properties: a mini review. Curr. Microbiol. 76, 783-790. doi: 10.1007/s00284-018-1557-2

Murugan, T. (2012). Antibacterial activity of c-phycocyanin against clinical isolates by disc diffusion method. J. Pharm. Res. 5, 3020-3021.

Musa, N. N., and Yusof, N. Z. (2019). Chemical and physical parameters affecting bacterial pigment production. Mater. Today Proc. 18, 1608-1617. doi: 10.1016/j.matpr.2019.11.189

Namazkar, S., Garg, R., Ahmad, W. A., and Nordin, N. (2013). Production and characterization of crude and encapsulated prodigiosin pigment. Int. J. Chem. Sci. Appl. 4, 116-129.

Nasrabadi, M., and Razavi, S. (2011). Optimization of b-carotene production by a mutant of the lactose-positive yeast Rhodotorula achenorium from whey ultrafiltrate. Food. Sci. Biotech. 20, 445-454. doi: 10.1007/s10068-011-0062-1

Neeraj, N., Neera, M., and Sayan, C. (2011). Microbial pigments with health benefits-a mini review. Trends Biotechnol. 4, 157-160.

Nigam, P. S., and Luke, J. S. (2016). Food additives: production of microbial pigments and their antioxidant properties. Curr. Opin. Food Sci. 7, 93-100. doi: 10.1016/j.cofs.2016.02.004

Norman, R. S., Moeller, P., Mc Donald, T. J., and Morris, P. J. (2004). Effect of pyocyanin on a crude oil degrading microbial community. Appl. Environ. Microbiol. 70, 4004-4011. doi: 10.1128/AEM.70.7.4004-4011.2004

Numan, M., Bashir, S., Mumtaz, R., Tayyab, S., Rehman, N., Khan, A. L., et al. (2018). Therapeutic applications of bacterial pigments: a review of current status and future opportunities. Biotech. 8:207. doi: 10.1007/s13205-018-1227-x

Ozkan, G., and Ersus, B. S. (2014). Microencapsulation of natural food colorants. Int. J. Nutr. Food Sci. 3, 145-156.

Pal, M. P., Vaidya, B. K., Desai, K. M., Joshi, R. M., Nene, S. N., and Kulkarni, B. D. (2009). Media optimization for biosurfactant production by Rhodococcus Erythropolis MTCC 2794: artificial intelligence versus a statistical approach. J. Ind. Microbiol. Biotechnol. 36, 747-756. doi: 10.1007/s10295-009-0547-6
Panesar, R., Kaur, S., and Panesar, P. S. (2015). Production of microbial pigments utilizing agro-industrial waste: a review. Curr. Opin. Food Sci. 1,70-76. doi: 10.1016/j.cofs.2014.12.002

Pantanella, F., Berlutti, F., Passariello, C., Sarli, S., Morea, C., and Schippa, S. (2007). Violacein and biofilm production in Janthinobacterium lividum. J. Appl. Microbiol. 102, 992-999. doi: 10.1111/j.1365-2672.2006.03155.x

Paola-Rosanna, D., and Salvatore, C. (2012). Reactive oxygen species, inflammation, and lung diseases. Curr. Pharm. Des. 18, 3889-3900. doi: 10.2174/138161212802083716

Park, S. Y., Binkley, R. M., Kim, W. J., Lee, M. H., and Lee, S. Y. (2018). Metabolic engineering of Escherichia coli for high-level astaxanthin production with high productivity. Metabol. Eng. 49, 105-115. doi: 10.1016/j.ymben.2018.08.002

Pasarin, D., and Rovinaru, C. (2018). Sources of carotenoids and their uses as animal feed additives - a review. Sci. Paper 61, 75-85.

Pham, J. V., Yilma, M. A., Feliz, A., Majid, M. T., Maffetone, N., Walker, J. R., et al. (2019). A review of the microbial production of bioactive natural products and biologics. Front. Microbiol. 10:1404. doi: 10.3389/fmicb.2019.01404

Pilkington, J. L., Preston, C., and Gomes, R. L. (2014). Comparison of response surface methodology and artificial neural network towards efficient extraction of artemisinin from Artemisia annua. Indus. Crop. Prod. 58, 15-24. doi: 10.1016/j.indcrop.2014.03.016

Prabhu, S., Rekha, P. D., and Arun, A. B. (2013). Evaluation of antioxidant activity of carotenoid isolated from Fontibacter flavus YUAB-SR-25. Int. J. Nat. Prod. Res. 3, 62-67.

Prathibha, S., Latha, B., and Suamthi, G. (2017). Particle swarm optimization based workflow scheduling for medical applications in cloud. Biomed. Res. 1, 1-1.

Qian, C., Decker, E. A., Xiao, H., and McClements, D. J. (2012). Physical and chemical stability of $\beta$-carotene-enriched nanoemulsions: influence of $\mathrm{pH}$, ionic strength, temperature, and emulsifier type. Food Chem. 132, 1221-1229. doi: 10.1016/j.foodchem.2011.11.091

Radhakrishnan, M., Gopikrishnan, V., Vijayalakshmi, G., and Kumar, V. (2016). In vitro antioxidant activity and antimicrobial activity against biofilm forming bacteria by the pigment from the desert soil Streptomyces sp. D25. J. Appl. Pharm. Sci. 6, 148-150. doi: 10.7324/JAPS.2016.60626

Ram, S., Mitra, M., Shah, F., Tirkey, S. R., and Mishra, S. (2020). Bacteria as an alternate biofactory for carotenoid production: a review of its applications, opportunities and challenges. J. Funct. Food. 67:103867. doi: 10.1016/j.jff.2020.103867

Ramesh, C., Vinithkumar, N. V., Kirubagaran, R., Venil, C. K., and Dufossé, L. (2019). Multifaceted applications of microbial pigments: current knowledge, challenges and future directions for public health implications. Microorg. 6:186. doi: 10.3390/microorganisms7070186

Rao, M. P. N., Xiao, M., and Li, W. J. (2017). Fungal and bacterial pigments: secondary metabolites with wide applications. Front. Microbiol. 8:1113. doi: $10.3389 /$ fmicb. 2017.01113

Ravikumar, S., Uma, G., and Gokulakrishnan, R. (2016). Antibacterial property of Halobacterial carotenoids against human bacterial pathogens. J. Sci. Ind. Res. 75, 253-257.

Ravin, S., Gourav, C., Anterpret, C., and Reena, V. S. (2017). Antioxidant and anticancer activity of methanolic extract from Stephania elegans. Int. J. Pharm. Sci. 9, 245-249. doi: 10.22159/ijpps.2017v9i2.16204

Reverchon, S., Rouanet, C., Expert, D., and Nasser, W. (2002). Characterization of indigoidine biosynthetic genes in Erwinia chrsanthemi and role of this blue pigment in pathogenicity. J. Bacteriol. 184, 654-665. doi: 10.1128/JB.184.3.654-665.2002

Rezaeeyan, Z., Safarpour, A., Amoozegar, M. A., Babavalian, H., Tebyanian, H., and Shakeri, F. (2017). High carotenoid production by a halotolerant bacterium, Kocuria sp. strain QWT-12 and anticancer activity of its carotenoid. EXCLI J. 16, 840-851. doi: 10.17179/excli2017-218

Ring, L. C., Yenn, T. W., Nazri, N. I., Nee, T. W., Zahan, K. A., Ibrahim, D., et al. (2018). Chemical optimization of red pigment, monascorubin production in penicillium minioluteum ED24 using solid state fermentation. Arab. J. Sci. Eng. 43, 3485-3491. doi: 10.1007/s13369-018-3182-6

Rocha, G., Trindade, F. C., and Grosso, F. C. (2012). Microencapsulaiton of lycopene by spray dring: characterization, stability and applications of microcapsules. Food Bioprod. Process 90, 37-42. doi: 10.1016/j.fbp.2011.01.001

Rodrigues, A. L., Trachtmann, N., Becker, J., Lohanatha, A. F., Blotenberg, J., Bolten, C. J., et al. (2013). Systems metabolic engineering of Escherichia colifor 
production of the antitumor drugs violacein and deoxyviolacein. Meta. Eng. 20, 29-41. doi: 10.1016/j.ymben.2013.08.004

Rodriguez-Amaya, D. B. (2016). Natural food pigments and colorants. Curr. Opin. Food Sci. 7, 20-26. doi: 10.1016/j.cofs.2015.08.004

Romanenko, L. A., Tanaka, N., Svetashev, V. I., Kalinovskaya, N. I., and Mikhailov, V. V. (2015). Rheinheimera japonica sp. nov., a novel bacterium with antimicrobialactivity from seashore sediments of the sea of Japan. Arch. Microbiol. 197, 613-620. doi: 10.1007/s00203-015-1095-2

Rosas, J. C., Ferreira-Grosso, C. R., Gomez-Aldapa, C. A., Rangel-Vargas, E., Rodrigues-Martin, M. L., Guzman-Ortiz, F. A., et al. (2017). Recent advances in microencapsulation of natural sources of antimicrobial compounds used in food - a review. Food Res. Int. 102, 575-587. doi: 10.1016/j.foodres.2017.09.054

Ryalat, M. H., Emmens, D., Hulse, M., Bell, D., AlRahamneh, Z., Laycock, S., et al. (2016). "Evaluation of particle swarm optimisation for medical image segmentation," in International Conference on Systems Science, eds J. Świątek and J. M. Tomczak (Springer International Publishing), 61-72. doi: 10.1007/978-3-319-48944-5_6

Saini, D. K., Chakdar, H., Pabbi, S., and Shukla, P. (2020). Enhancing production of microalgal biopigments through metabolic and genetic engineering. Crit. Rev. Food Sci. Nutr. 60, 391-405. doi: 10.1080/10408398.2018.1533518

Saini, R. K., and Keum, Y. S. (2019). Microbial platforms to produce commercially vital carotenoids at industrial scale: An updated review of critical issues. J. Ind. Microbiol. Biotechnol. 46, 657-674. doi: 10.1007/s10295-018-2104-7

Sajilata, M. G., Singhal, R. S., and Kamat, M. Y. (2008). The carotenoid pigment zeaxanthin. Compr. Rev. Food Sci. Food Saf. 7:29e41. doi: 10.1111/j.1541-4337.2007.00028.x

Salehi, M., and Goorkani, M. M. (2017). Optimum allocation of Iranian oil and gas resources using multi-objective linear programming and particle swarm optimization in resistive economy conditions. J. Ind. Syst. Eng. 10, 43-68.

Sankari, M., Rao, P. R., Hemachandran, H., Pullela, P. K., Doss, C. G. P., Tayubi, I. A., et al. (2018). Prospects and progress in the production of valuable carotenoids: Insights frommetabolic engineering, synthetic biology, and computational approaches. J. Biotechnol. 266, 89-101. doi: 10.1016/j.jbiotec.2017.12.010

Saraiva, V. S., Marshall, J. C., Lartigue, C. J., and Burnier, M. N. (2004). Cytotoxic effects of violacein in human uveal melanoma cell lines. Melanoma Res. 14, 421-424. doi: 10.1097/00008390-200410000-00014

Sathasivam, R., and Ki, J. S. (2018). A review of the biological activities of microalgal carotenoids and their potential use in healthcare and cosmetic industries. Mar. Drugs 16:26. doi: 10.3390/md16010026

Schoner, T. A., Fuchs, S. W., Hurek, B. R., and Bode, H. B. (2014). Identification and biosynthesis of a novel xanthomonadin-dialkylresorcinol hybrid from Azoarcus sp. BH72. PLoS ONE 9:e90922. doi: 10.1371/journal.pone.00 90922

Schramm, A., Matusik, P., Osmenda, G., and Guzik, T. J. (2012). Targeting NADPH oxidases in vascular pharmacology. Vascul. Pharmacol. 30, 216-231. doi: 10.1016/j.vph.2012.02.012

Schwechheimer, S. K., Park, E. Y., Revuelta, J. L., Becker, J., and Wittmann, C. (2016). Biotechnology of riboflavin. Appl. Microbiol. Biotechnol. 100, 2107-2119. doi: 10.1007/s00253-015-7256-Z

Scotter, M. J. (2015). "Overview of EU regulations and safety assessment for food colours," in Colour Additives for Foods and Beverages, ed M. J. Scotter (Amsterdam: Elsevier), 61-74. doi: 10.1016/B978-1-78242-011-8.00003-9

Selvameenal, L., Radhakrishnan, M., and Balagurunathan, R. (2009). Antibiotic pigment from desert soil actinomycetes: biological activity, purification and chemical screening. Indian J. Pharm. Sci. 71, 499-504. doi: 10.4103/0250-474X.58174

Sen, T., Barrow, C. J., and Deshmukh, S. K. (2019). Microbial pigments in the food industry - challenges and the way forward. Front. Nutr. 6:7. doi: 10.3389/fnut.2019.00007

Siavashi, M., and Doranehgard, M. H. (2017). Particle swarm optimization of thermal enhanced oil recovery from oilfields with temperature control. Appl. Therm. Eng. 123, 658-669. doi: 10.1016/j.applthermaleng.2017.05.109

Sibero, M. T., Bachtiarini, T. U., Trianto, A., Lupita, A. H., Sari, D. P., Igarashi, Y., et al. (2019). Characterization of a yellow pigmented coral associated bacterium exhibiting anti-bacterial activity against multidrug resistant organism. Egyp. J. Aqua. Res. 45, 81-87. doi: 10.1016/j.ejar.2018.11.007
Sikkandar, S., Murugan, K., Al-Sohaibani, S., Rayappan, F., Nair, A., and Tilton, F. (2013). Halophilic bacteria - a potent source of carotenoids with antioxidant and anticancer potenials. J. Pure Appl. Microbiol. 7, 2825-2830.

Silva, F. E., Figueira, F. S., Cañedo, A. D., Machado, K. S., Salgado, M. T. S. F., Silva, T.K., et al. (2018). C-phycocyanin to overcome the multidrug resistance phenotype in human erythroleukemias with or without interaction with ABC transporters. Biomed. Pharmather. 106, 532-542. doi: 10.1016/j.biopha.2018.06.145

Silva, I., Stringheta, C., Teofilo, F., and Oliver, N. I. (2013). Parameter optimization for spray drying microencapsulation of jaboticaba peel extracts using simultaneous analysis of responses. J. Food. Eng. 117, 538-544. doi: 10.1016/j.jfoodeng.2012.08.039

Singh, V., Haque, S., Niwas, R., Srivastava, A., Pasupuleti, M., and Tripathi, C. K. M. (2016). Strategies for fermentation medium optimization: an in-depth review. Front. Microbiol. 7:2087. doi: 10.3389/fmicb.2016.02087

Soesanti, I., and Syahputra, R. (2016). Batik production process optimization using particle swarm optimization method. J. Theor. Appl. Info. Technol. 86, 272.

Solieve, A. B., Hosokawa, K., and Enomoto, K. (2011). Bioactive pigments from marine bacteria: applications and physiological roles. Evide Based Compl Alternat Med. 670349:17. doi: 10.1155/2011/670349

Spada, C., Norena, Z. C., Marezak, F. L., and Tessaro, I. C. (2012). Study on the stability of $\beta$-carotene microencapsulated with pinhão (Araucaria angustifolia seeds) starch. Car. Pol. 89, 1166-1173. doi: 10.1016/j.carbpol.2012.03.090

Srilekha, V., Krishna, G., Mahender, P., and Charya, M. A. S. (2018). Investigation of in vitro cytotoxic activity of pigment extracted from Salinococcus sp. isolated from Nellore sea coast. J. Mar. Med. Soc. 20, 31-33. doi: 10.4103/jmms.jmms_56_17

Srilekha, V., Krishna, G., Srinivas, V. S., and Charya, M. A. S. (2017). Antimicrobial evaluation of bioactive pigment from Salinococcus sp isolated from Nellore sea coast. Int. J. Biotechnol. Biochem. 13, 211-217.

Stankovic, N., Radulovic, V., Petkovic, M., Vuckovic, I., Jadranin, M., Vasiljevic, B., et al. (2012). Streptomyces sp. JS520 produces exceptionally high quantities of undecylprodigiosin with antibacterial, antioxidative, and UV-protective properties. Appl. Microbial. Biotechnol. 96, 1217-1231. doi: 10.1007/s00253-012-4237-3

Su, A., Chi, S., Li, Y., Tan, S., Qiang, S., Chen, Z., et al. (2018). Metabolic redesign of Rhodobacter sphaeroides for lycopene production. J. Agric. Food Chem. 66, 5879-5885. doi: 10.1021/acs.jafc.8b00855

Suresh, M., Renugadevi, B., Brammavidhya, S., Iyapparaj, P., and Anantharaman, P. (2015). Antibacterial activity of red pigment produced by Halolactibacillus alkaliphilus MSRD1-an isolate from seaweed. Appl. Biochem. Biotechnol. 176, 185-195. doi: 10.1007/s12010-015-1566-6

Surwase, S. N., Jadhav, S. B., Phugare, S. S., and Jadhav, J. P. (2013). Optimization of melanin production by Brevundimonas sp. SGJ using response surface methodology. Biotech 3, 187-194. doi: 10.1007/s13205-0120082-4

Tarangini, K., and Mishra, S. (2013). Production, characterization and analysis of melanin from isolated marine Pseudomonas sp. using vegetable waste. Res. J. Eng. Sci. 2, 40-46.

Tendulkar, P. A., Surve, M. A., and Deodhar, M. A. (2018). Sun protective formulation from carotenoids extracted from thermotolerant genera Synechocystis pevalekii. Int. J. Pharm. Sci. Res. 12, 3223-3234.

Thogersen, M. S., Delpin, M. W., Melchiorsen, J., Kilstrup, M., Mansson, M., Bunk, B., et al. (2016). Production of bioactive compounds violacein and indolmycin is conditional in a maeA mutant of Pseudoalteromonas luteoviolacea S4054 lacking the malic enzyme. Front. Microbiol. 7:1461. doi: $10.3389 /$ fmicb. 2016.01461

Tuli, H. S., Chaudhary, P., Beniwal, V., and Sharma, A. K. (2015). Microbial pigments as natural color sources: current trends and future perspectives. $J$. Food Sci. Technol. 52, 4669-4678. doi: 10.1007/s13197-014-1601-6

Usman, H. M., Abdulkadir, N., Gani, M., and Maiturare, H. (2017). Bacterial pigments and its significance. MOJ Bioequiv. Avail. 4, 285-288. doi: 10.15406/mojbb.2017.04.00073

Valla, A., Cartier, D., Valla, B., Le Guillou, R., Andriamialisoa, Z., Labia, R., et al. (2003). New syntheses of natural carotene isorenieratene $(\phi, \phi-$ carotene) and its 3,3'-dimethoxy analog. Helvet. Chim. Acta 86, 3314-3319. doi: $10.1002 /$ hlca.200390273 
Van-Duin, D., and Paterson, D. (2017). Multidrug resistant bacteria in community: trendsand lesson learned. Infect. Dis. Clin. North Am. 30, 377-390. doi: 10.1016/j.idc.2016.02.004

Venegas, F. A., Kollisch, G., Mark, K., Diederich, W. E., Kaufmann, A., Bauer, S., et al. (2019). The bacterial product violacein exerts an immunostimulatory effect via TLR 8. Sci. Rep. 9:13661. doi: 10.1038/s41598-019-50038-x

Venil, C. K., Aruldass, C. A., Dufossé, L., Zakaria, Z. A., and Ahmad, W. A. (2014). Current perspective on bacterial pigments: emerging sustainable compounds with coloring and biological properties for the industry-an incisive evaluation. RSC Adv. 4, 39523-39529. doi: 10.1039/C4RA06162D

Venil, C. K., Khasim, A. R., Aruldass, C. A., and Ahmad, W. A. (2016). Microencapsulation of flexirubin type pigment by spray drying: characterization and antioxidant activity. Int. Biodeter. Biodegr. 113, 350-356. doi: 10.1016/j.ibiod.2016.01.014

Venil, C. K., Zakaria, Z. A., and Ahmad, W. A. (2013). Bacterial pigments and their applications. Process Biochem. 48, 1065-1079. doi: 10.1016/j.procbio.2013.06.006

Venil, C. K., Zakaria, Z. A., and Ahmad, W. A. (2015). Optimization of culture conditions for flexirubin production by Chryseobacterium artocarpi CECT8497 using response surface methodology. Acta Biochim. Pol. 2, 185-190. doi: $10.18388 / a b p .2014 \_870$

Venil, C. K., Devi, P. R., and Ahmad, W. A. (2020). "Agro-industrial wastes as substrates for the production of bacterial pigment," in Valorisation of Agro-Industrial Residues-Volume I: Biological Approaches, eds Z. A. Zakaria, R. Boopathy, and J. R. Dib (Switzerland: Springer). doi: 10.1007/978-3-030-39137-9_7

Vila, E., Hornero-Mendez, D., Azziz, G., Lareo, C., and Saravia, V. (2019). Carotenoids from heterotrophic bacteria isolated from Fildes Peninsula, King George Island, Antarctica. Biotechnol. Rep. 21:e00306. doi: 10.1016/j.btre.2019.e00306

Wagh, P., and Mane, R. (2017). Identification and characterization of extracellular red pigment producing Neisseria spp. isolated from soil sample. Int. J. Innov. Knowl. Concept 5, 23-25.

Walsh, J. G., Cullen, S. P., Sheridan, C., Lüthi, A. U., Gerner, C., and Martin, S. J. (2008). Executioner caspase-3 and caspase-7 are functionally distinct proteases. Proc. Natl. Acad. Sci. U.S.A. 105, 12815-12819. doi: 10.1073/pnas.0707 715105

Wang, H., Jiang, P., Lu, Y., Ruan, Z., Jiang, R., Xing, X. H., et al. (2009). Optimization of culture conditions for violacein production by a new strain of Duganella sp. B2. Biochem. Eng. J. 44, 119-124. doi: 10.1016/j.bej.2008. 11.008

Wang, Q., Liu, D., Yang, Q., and Wang, P. (2017). Enhancing carotenoid production in Rhodotorula mucilaginosa KC8 by combining mutation and metabolic engineering. Ann. Microbiol. 67, 425-431. doi: 10.1007/s13213-017-1274-2

Wang, S. L., Yang, C. H., Liang, T. W., and Yen, Y. H. (2008). Optimization of conditions for protease production by Chryseobacterium Taeanense TKU001. Bioresourc. Technol. 99, 3700-3707. doi: 10.1016/j.biortech.2007.07.036

Wang, Y., Fang, X., An, F., Wang, G., and Zhang, X. (2011). Improvement of antibiotic activity of Xenorhabdus bovienii by medium optimization using response surface methodology. Microb. Cell Fact. 10, 1-15 doi: 10.1186/1475-2859-10-98

Wang, Y., Nakajima, A., Hosokawa, K., Soliev, A. B., Osaka, I., Arakawa, R., et al. (2012). Cytotoxicity prodigiosin family pigments from Pseudoalteromonas sp. 1020R isolated from the Pacific coast of Japan. Biosci. Biotechnol. Biochem. 76, 1229-1232. doi: 10.1271/bbb.110984

Watstein, D. M., McNerney, M. P., and Styczynski, M. P. (2015). Precise metabolic engineering of carotenoid biosynthesis in E.coli towards a low cost biosensor. Metab. Eng. 31, 171-180. doi: 10.1016/j.ymben.2015.06.007

Wehrs, M., Tanjore, D., Eng,. T., Lievense, J., Pray, T. R., and Mukhopadhyay, A. (2019). Engineering robust production of microbes for large scale cultivation. Trend. Microbiol. 27, 524-537. doi: 10.1016/j.tim.2019.01.006

Xu, X., Tian, L., Xu, J., Xie, C., Jiang, L., and Huang, H. (2018). Analysis and expression of the carotenoid biosynthesis genes from Deinococcus wulumuqiensis R12 in engineered Escherichia coli. AMB Express, 8:94. doi: 10.1186/s13568-018-0624-1

Yada, S., Wang, Y., Zou, Y., Nagasaki, K., Hosokawa, K., Osaka, I., et al. (2008). Isolation and characterization of two groups of novel marine bacteria producing violacein. Mar. Biotechnol. 10, 128-132. doi: 10.1007/s10126-007-9046-9

Yadav, V. G., DeMey, M., Lim, C. G., Ajikumar, P. K., and Stephanopoulos, G. (2012). The future of metaolic engineering and synthetic biology: towards a systematic practice. Metab. Eng. 14, 233-241. doi: 10.1016/j.ymben.2012.02.001

Yi, J., Lam, T. I., Yokoyama, W., Cheng, L. W., and Zhong, F. (2014). Cellular uptake of beta carotene from protein stabilized solid lipid nanoparticles prepared by homogenization evaporation method. J. Agric. Food Chem. 62, 1096-1104. doi: 10.1021/jf404073c

Yoon, S. H., Lee, Y. M., Kim, J. E., Lee, S. H., Lee, J. H., Kim, J. Y., et al. (2006). Enhanced lycopene production in Escherichia coli engineered to synthesize isopentenyl diphosphate and dimethylallyl diphosphate from mevalonate. Biotechnol. Bioeng. 94, 1025-1032. doi: 10.1002/bit. 20912

Zerrad, A., Anissi, J., Ghanam, J., Sendide, K., and Hassouni, M. (2014). Antioxidant and antimicrobial activities of melanin produced by a Pseudomonas balearica strain. J. Biotechnol. Lett. 5, 87-94.

Zhao, J., Wu, Y., Alfred, A. T., Wei, P., and Yang, S. (2014). Anticancer effects of pyocyanin on HepG2 human hepatoma cells. Lett. Appl. Microbiol. 58, 541-548. doi: 10.1111/lam.12224

Conflict of Interest: The authors declare that the research was conducted in the absence of any commercial or financial relationships that could be construed as a potential conflict of interest.

Copyright (c) 2020 Venil, Dufossé and Renuka Devi. This is an open-access article distributed under the terms of the Creative Commons Attribution License (CC BY). The use, distribution or reproduction in other forums is permitted, provided the original author(s) and the copyright owner(s) are credited and that the original publication in this journal is cited, in accordance with accepted academic practice. No use, distribution or reproduction is permitted which does not comply with these terms. 